\title{
Biochar to improve soil fertility. A review
}

\author{
Yang Ding ${ }^{1,2}$ - Yunguo Liu ${ }^{1,2} \cdot$ Shaobo $\operatorname{Liu}^{3,4} \cdot$ Zhongwu Li $^{1,2} \cdot$ Xiaofei Tan ${ }^{1,2}$. \\ Xixian Huang ${ }^{1,2} \cdot$ Guangming Zeng $^{1,2} \cdot$ Lu Zhou $^{1,2} \cdot$ Bohong Zheng $^{3}$
}

\begin{abstract}
Soil mineral depletion is a major issue due mainly to soil erosion and nutrient leaching. The addition of biochar is a solution because biochar has been shown to improve soil fertility, to promote plant growth, to increase crop yield, and to reduce contaminations. We review here biochar potential to improve soil fertility. The main properties of biochar are the following: high surface area with many functional groups, high nutrient content, and slow-release fertilizer. We discuss the influence of feedstock, pyrolysis temperature, $\mathrm{pH}$, application rates, and soil types. We review the mechanisms ruling the adsorption of nutrients by biochar.
\end{abstract}

Keywords Biochar $\cdot$ Soil $\cdot$ Fertility $\cdot$ Nutrient $\cdot$ Mechanism

Yunguo Liu

hnliuyunguo@163.com

1 College of Environmental Science and Engineering, Hunan University, Changsha 410082, People's Republic of China

2 Key Laboratory of Environmental Biology and Pollution Control, Hunan University, Ministry of Education, Changsha 410082, People's Republic of China

3 School of Architecture and Art Central South University, Central South University, Changsha 410082, People's Republic of China

4 School of Metallurgy and Environmental, Central South University, Changsha 410083, People's Republic of China

\section{Contents}

1. Introduction

2. Biochar as a source of nutrients

2.1 The potential of biochar as fertilizer

2.2 Factors affecting nutrient content and availability in biochars

3. The influence of biochar on properties of soils

3.1 The effect of biochar on physical and chemical properties of soils

3.2 Influencing factors of biochar function

4. Adsorption and release of nutrients from biochar

4.1 Adsorption of nutrient and application as slowrelease fertilizer

4.2 The retention of soil nutrient by biochar

5. Biochar, microorganism, and fertility

5.1. Influence of biochar on microorganisms community 5.1.1 Influence of biochar on microbial abundance 5.1.2 Influence of biochar on microbial community composition and structure

5.2 Influence of biochar on microbial activity

5.3 Impact of biochar on functional ecology of microorganisms

6. Negative effects of biochar on soil biota

7. Discussions

8. Conclusions

9. Acknowledgments

10. References 


\section{Introduction}

The needs to develop more sustainable agriculture systems and improve weak rural economies necessitate major changes in agriculture management. Soil degradation, including decreased fertility and increased erosion, is a major concern in global agriculture (Jianping 1999). Long-term cultivation of soils could result in degradation, containing soil acidification, soil organic matter depletion, and severe soil erosion (De Meyer et al. 2011). Furthermore, the decrease in soil organic matter decreases the aggregate stability of soil (Annabi et al. 2011). Therefore, it is crucial to remediate the degradation soils by simple and sustainable methods.

Manures and composts contain pathogens, heavy metals, and pharmaceuticals, which may cause long-term contamination of farmland. Moreover, manures and composts have the potential to lead to ammonia and methane releases, which can aggravate global warming and serious groundwater and stream nutrient pollution. Being a renewable resource and due to its economic and environmental benefits (Fig. 1), biochar is a promising resource for soil's fertility management. Furthermore, biochar loaded with ammonium, nitrate, and phosphate could be also proposed to be a slow-release fertilizer to enhance soil fertility (Spokas et al. 2012; Xu et al. 2014; Schmidt et al. 2015; Kammann et al. 2015).

Biochar is the by-product of biomass pyrolysis in an oxygen depleted atmosphere. It contains porous carbonaceous structure and an array of functional groups (Lehmann and Joseph 2009).

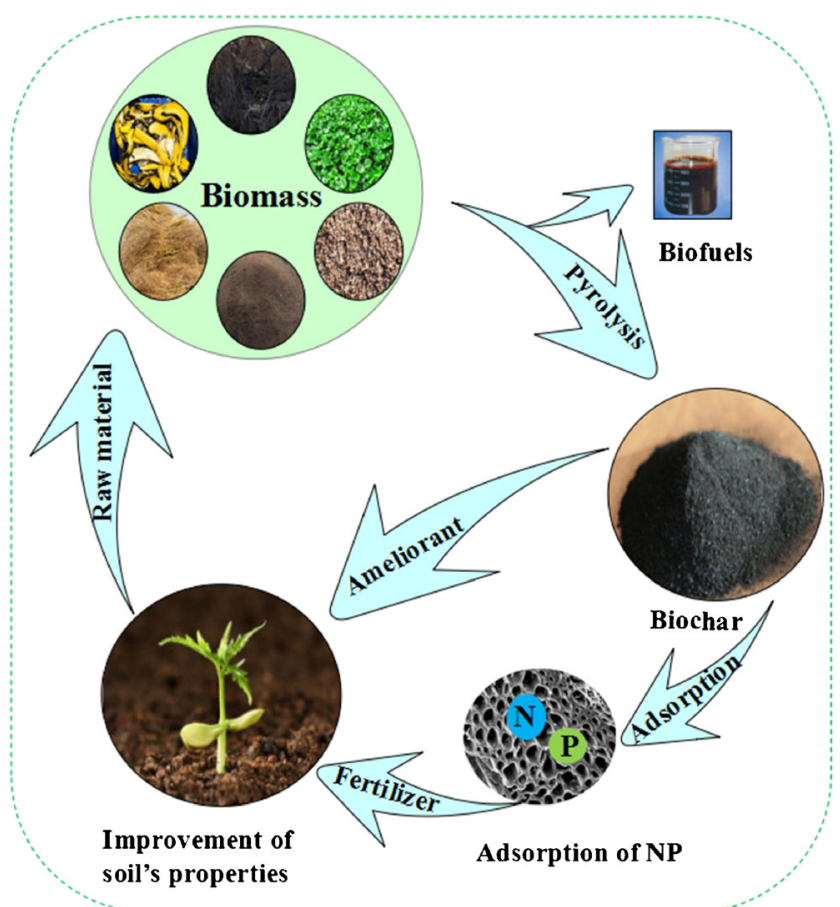

Fig. 1 The benefits of biochar applied as a tool for soil fertility management
Biochar's highly porous structure can contain amounts of extractable humic-like and fluvic-like substances (Lin et al. 2012). Moreover, its molecular structure shows a high degree of chemical and microbial stability (Cheng et al. 2008a). The physical and chemical properties of biochar are highly dependent on pyrolysis temperature and process parameters, such as residence time and furnace temperature, as well as on the feedstock type (Joseph et al. 2010; Bruun et al. 2011). A wide range of common raw materials are used as the feedstock, including wood chip, organic wastes, plant residues, and poultry manure (Sohi et al. 2010). The elemental composition of biochar generally include carbon, nitrogen, hydrogen, and some lower nutrient element, such as $\mathrm{K}, \mathrm{Ca}, \mathrm{Na}$, and $\mathrm{Mg}$ (Zhang et al. 2015). Commonly, the carbon content increased with increasing pyrolysis temperature from 300 to $800{ }^{\circ} \mathrm{C}$, while the contents of nitrogen and hydrogen decreased. Biochar has a high specific surface area and a number of polar or nonpolar substances, which has a strong affinity to inorganic ions such as heavy metal ions, phosphate, and nitrate (Schmidt et al. 2015; Kammann et al. 2015).

Biochar was reported to improve not only soil chemical and physical properties but also soil microbial properties. Many studies indicated that the combination of biochar with soils could improve soil structure, increase porosity, decrease bulk density, and enhance aggregation and water retention (Baiamonte et al. 2015). In addition, biochar can increase soil electrical conductivity by $124.6 \%$ (Oguntunde et al. 2004) and cation exchange capacity by $20 \%$ (Laird et al. 2010), while reduce soil acidity by $31.9 \%$ (Oguntunde et al. 2004). Moreover, biochar has also been tested to increase soil biological community composition (Grossman et al. 2010) and microbial biomass by $125 \%$ (Liang et al. 2010). Steiner et al. (2008a) indicated that, after biochar application, basal respiration increased about by $30.1 \% \mathrm{CO}_{2}$ in the following $35 \mathrm{~h}$ after substrate addition.

In recent years, an increasing interest in applying biochar is focused on the amendment of nutrient-poor soil for soil ecological restoration including sequestering carbon (Jiang et al. 2012; Liu et al. 2012). Various mechanisms have been suggested for the increase of plant nutrient availability in nutrientlimited agroecosystems such as (1) the initial addition of soluble nutrients contained in the biochar (Sohi et al. 2010) and the mineralization of the labile fraction of biochar containing organically bound nutrients (Lehmann et al. 2009); (2) reduction of nutrient leaching due to biochar's physicochemical properties (Liang et al. 2006); (3) lower escapable $\mathrm{N}$ losses by ammonia volatilization and $\mathrm{N}_{2}$ and $\mathrm{N}_{2} \mathrm{O}$ from denitrification (Cayuela et al. 2013); and (4) a retention of N, P, and S associated with the increase in biological activities or community shifts (Pietikäinen et al. 2000). In the field trials, many researchers reported that biochar application improved soil quality, increased crop production and promoted plant growth (Lehmann et al. 2006; Major et al. 2010; Zhang et al. 2010) (Table 1). Uzoma et al. (2011) found that, compared to the control, maize grain yield significantly increased by 150 and 
Table 1 Effects of biochar addition on crop yield

\begin{tabular}{|c|c|c|c|c|c|}
\hline Biochar type & $\begin{array}{l}\text { Biochar rate } \\
\left(\mathrm{t} \mathrm{ha}^{-1}\right)\end{array}$ & Crops & Soil type & $\begin{array}{l}\text { Yield/biomass increase } \\
\text { over control }(\%)\end{array}$ & Reference \\
\hline \multirow[t]{3}{*}{ Secondary forest wood } & 68 & Cowpea & Xanthic Ferralsol & 20 & \multirow[t]{3}{*}{ Glaser et al. (2002) } \\
\hline & 136.75 & Cowpea & Xanthic Ferralsol & 100 & \\
\hline & 68 & Rice & Xanthic Ferralsol & 50 & \\
\hline \multirow{2}{*}{ Poultry litter } & 10 & Radish & Alfisol & 42 & \multirow{2}{*}{ Chan et al. $(2008 \mathrm{a}, \mathrm{b})$} \\
\hline & 50.5 & Radish & Alfisol & 96 & \\
\hline Orchard pruning & 22 & Grape & Sandy clay loam & 20 & Genesio et al. (2015) \\
\hline Charcoal & 0.5 & Moong & Dehli soil & 22 & Glaser et al. (2002) \\
\hline Greenwaste & 100 & Radish & Alfisol & 266 & Chan et al. (2008a, b) \\
\hline Cow manure & 15 & Maize & Sandy soil & 150 & Uzoma et al. (2011) \\
\hline Logs of Eucalyptus deglupta & 30 & Rice & Inceptisol & 294 & Noguera et al. (2010) \\
\hline Wheat straw & 40 & Rice & Paddy soil & 14 & Zhang et al. (2010) \\
\hline \multirow[t]{3}{*}{ Hardwood } & 19 & Maize & Midwestern mollisols & 10 & \multirow[t]{3}{*}{ Rogovska et al. (2014) } \\
\hline & 38 & Maize & Midwestern mollisols & 17 & \\
\hline & 58 & Maize & Midwestern mollisols & 48 & \\
\hline \multirow[t]{2}{*}{ Wheat straw } & 40 & Rapeseed & Upland red soil & 36.02 & \multirow[t]{2}{*}{ Liu et al. (2014) } \\
\hline & 40 & Sweet potato & Upland red soil & 53.77 & \\
\hline \multirow[t]{3}{*}{ Black carbon } & 20 & Maize & Oxisol & 28 (the second year) & \multirow[t]{3}{*}{ Major et al. (2010) } \\
\hline & 20 & Maize & Oxisol & 30 (the third year) & \\
\hline & 20 & Maize & Oxisol & 140 (the fourth year) & \\
\hline
\end{tabular}

$98 \%$ after the application of biochar at 15 and $20 \mathrm{t} \mathrm{ha}^{-1}$, respectively. However, grain yield decreased by 23.3, 10, and $26.7 \%$ while the application rate of biochar was 4,8 , and $16 \mathrm{t} \mathrm{ha}^{-1}$, respectively (Asai et al. 2009). The decreased crop yield may be attributed to the high volatile matter, as well as toxic and harmful substance in biochar, which can reduce nutrient uptake and inhibit plant growth. Thereby, the improvements of crop production and plant growth may be dependent on the properties of biochar and soil. It is significant to understand the mechanisms which may induce changes on soil fertilizer after biochar application into soil.
In this review, we critically discussed the influence of biochar on soil properties, including soil physicochemical and biological properties. Moreover, the mechanisms of biochar in the improvement of soil fertility were also reviewed. In order to better understand the connections between biochar and soil, four following aspects are included in this paper (Fig. 2): (i) biochar as a source of nutrients; (ii) adsorption and desorption of nutrients on biochar; (iii) the influence of biochar on properties of soils; and (iv) the effects of biochar on biota in soil. The purpose of this review is to lay the foundation for future researches.
Fig. 2 The possible mechanisms for improving soil fertility






\section{Biochar as a source of nutrients}

\subsection{The potential of biochar as fertilizer}

Organic matter and inorganic salt, such as humic-like and fluvic-like substances and available $\mathrm{N}, \mathrm{P}$, and $\mathrm{K}$, can serve as fertilizer and be assimilated by plants and microorganisms. Lin et al. (2012) indicated that biochars produced from Acacia saligna at $380{ }^{\circ} \mathrm{C}$ and sawdust at $450{ }^{\circ} \mathrm{C}$ contained humics (humic-like and fluvic-like materials) of 17.7 and $16.2 \%$, respectively. Biochar made from Lantana camara at $300{ }^{\circ} \mathrm{C}$ contained available $\mathrm{P}\left(0.64 \mathrm{mg} \mathrm{kg}^{-1}\right)$, available $\mathrm{K}\left(711 \mathrm{mg} \mathrm{kg}^{-1}\right)$, available $\mathrm{Na}\left(1145 \mathrm{mg} \mathrm{kg}^{-1}\right)$, available $\mathrm{Ca}\left(5880 \mathrm{mg} \mathrm{kg}^{-1}\right)$, and available $\mathrm{Mg}\left(1010 \mathrm{mg} \mathrm{kg}^{-1}\right.$ ) (Masto et al. 2013). Similarly, fresh biochar had potential of nutrient availability and could release large amounts of $\mathrm{N}$ (23$635 \mathrm{mg} \mathrm{kg}^{-1}$ ) and $\mathrm{P}$ (46-1664 mg kg${ }^{-1}$ ) (Mukherjee and Zimmerman 2013; Zheng et al. 2013). Therefore, these data may indicate that biochar has great potential as available nutrients.

Although total N, P, and $\mathrm{K}$ in biochars may not necessarily reflect the actual availability of these nutrients to plants (Spokas et al. 2012), the available N, P, and $\mathrm{K}$ (e.g., ammonia $\left(\mathrm{NH}_{4}{ }^{+}\right)$, nitrate $\left(\mathrm{NO}_{3}{ }^{-}\right)$, phosphate $\left(\mathrm{PO}_{4}{ }^{3}\right.$ ${ }^{-}$) and $\mathrm{K}^{+}$) may be associated with the amounts of total $\mathrm{N}$, P, and K. For example, the loss of total $\mathrm{N}$ was contributed to the decrease of available $\mathrm{N}$ in higher temperatures biochars (Koutcheiko et al. 2007). Besides, the available $\mathrm{K}$ content significantly increased with the increase of total K amount (Zheng et al. 2013). Many current studies evaluated nutrients availability in biochars by conducting short-term column leaching experiments or using kinetic models. For instance, Wu et al. (2011) reported that $15-20 \%$ of $\mathrm{Ca}, 10-60 \%$ of $\mathrm{P}$, and about $2 \%$ of $\mathrm{N}$ in mallee wood biochar was readily leachable with distilled water after $24 \mathrm{~h}$. However, it is not sufficient to calculate the long-term nutrients availability of biochars. In the practical application, total $\mathrm{N}, \mathrm{P}$, and $\mathrm{K}$ in biochar could be used as an indirect indicator for choosing appropriate biochar.

\subsection{Factors affecting nutrient content and availability in biochars}

Nutrient contents in biochars were determined greatly by feedstock source and pyrolytic temperature (Table 2). For example, $\mathrm{N}$ losses began at about $400{ }^{\circ} \mathrm{C}$, then half of the $\mathrm{N}$ was lost as volatiles at about $750{ }^{\circ} \mathrm{C}$ in three woody and four herbaceous biochars (Lang et al. 2005). Moreover, the contents of available $\mathrm{N}$ (water-soluble) in biochars decreased from 39 to $8 \mathrm{mg} \mathrm{kg}^{-1}$ with the increase of pyrolysis temperatures from 350 to $600{ }^{\circ} \mathrm{C}$, which could be attributed to the loss of total $\mathrm{N}$ and the heterocyclization of $\mathrm{N}$ during pyrolysis (Zheng et al.
2013). Contrasted to total $\mathrm{N}$ content in biochars, total $\mathrm{P}$ content significantly increased from 0.12 to $0.17 \%$ with the increase of temperature from 300 to $600{ }^{\circ} \mathrm{C}$ (Zheng et al. 2013), which was attributed to the loss of carbon and relatively stable $\mathrm{P}$ in plant biomass in response to heating (Page et al. 1982). However, the available $\mathrm{P}$ in the biochars produced at lower temperature was much higher than the high-temperature biochars. Actually, the reasons could be explained that biochar contained less crystallized P-associated minerals in lower temperature biochars. Additionally, the total $\mathrm{K}$ content increased from $3.7 \%$ at $300{ }^{\circ} \mathrm{C}$ to $5.02 \%$ at $600{ }^{\circ} \mathrm{C}$, while the available $\mathrm{K}$ (water-soluble) content increased with the increase of pyrolysis temperature $\left(37 \%\right.$ at $300{ }^{\circ} \mathrm{C}$ and $47 \%$ at $600{ }^{\circ} \mathrm{C}$ ) (Zheng et al. 2013).

Additionally, biochars produced from different feedstocks present various nutrient elements composition. For instance, swine manure biochar produced at $400{ }^{\circ} \mathrm{C}$ contained large amounts of $\mathrm{N}(3.2 \%)$ and P (6.1\%) (Tsai et al. 2012), while Arundo donax biochar produced at $400{ }^{\circ} \mathrm{C}$ had little N $(0.69 \%)$ and $\mathrm{P}(0.13 \%)$ constituents (Zheng et al. 2013). Moreover, the ash content in the biochars made at $350{ }^{\circ} \mathrm{C}$ of poultry litter (30.7\%) (Cantrell et al. 2012) was much higher than that produced from pine wood chip at $350{ }^{\circ} \mathrm{C}(1.5 \%)$ (Spokas et al. 2011).

The $\mathrm{pH}$ of the soil is an important factor affecting nutrient availability of biochar (Silber et al. 2010). The release of $\mathrm{PO}_{4}{ }^{3-}$ and $\mathrm{NH}_{4}{ }^{+}$were $\mathrm{pH}$-dependent while the release of $\mathrm{K}^{+}$and $\mathrm{NO}_{3}{ }^{-}$was not (Zheng et al. 2013). Furthermore, at $\mathrm{pH} 2-7$, the content of $\mathrm{PO}_{4}{ }^{3-}$ and $\mathrm{NH}_{4}{ }^{+}$released from the biochars would be decreased with the increase of $\mathrm{pH}$ values, whereas that of $\mathrm{K}^{+}$remained relatively stable (Zheng et al. 2013). Similarly, the initial $\mathrm{Ca}$ and $\mathrm{Mg}$ release from corn straw biochar was also $\mathrm{pH}$-dependent, exhibiting an increase in released quantities as $\mathrm{pH}$ decreased from 8.9 to 4.5 (Silber et al. 2010).

The influence of application time on nutrient release from biochars should be considered. Zheng et al. (2013) set a series of time gradient to explore the relationship between time and water-soluble nutrients release by determining the concentration of $\mathrm{NH}_{4}{ }^{+}, \mathrm{PO}_{4}{ }^{3-}$, and $\mathrm{K}^{+}$. They found that the $\mathrm{NH}_{4}{ }^{+}$release from biochars produced from A. donax (giant reed) at 300 to $600{ }^{\circ} \mathrm{C}$ mainly occurred within $120 \mathrm{~h}$, indicating that these biochars contain slow-release $\mathrm{NH}_{4}{ }^{+}$, whereas the $\mathrm{PO}_{4}{ }^{3-}$ and $\mathrm{K}^{+}$release mainly occurred within $24 \mathrm{~h}$, indicating that these biochars contained fast-release $\mathrm{PO}_{4}{ }^{3-}$ and $\mathrm{K}^{+}$. Besides, high $\mathrm{C}$ mineralization and $\mathrm{N}$ immobilization of volatile matter in biochar by microorganisms could decrease the release of nutrients (Zimmerman 2010; Deenik et al. 2010). In practice, these influencing factors could be co-existence when biochar application into soil. Relatively, lower pyrolysis temperature and $\mathrm{pH}$ may increase the availability of $\mathrm{N}$ and $\mathrm{P}$, while higher pyrolysis temperature may increase the availability of $\mathrm{K}$. 


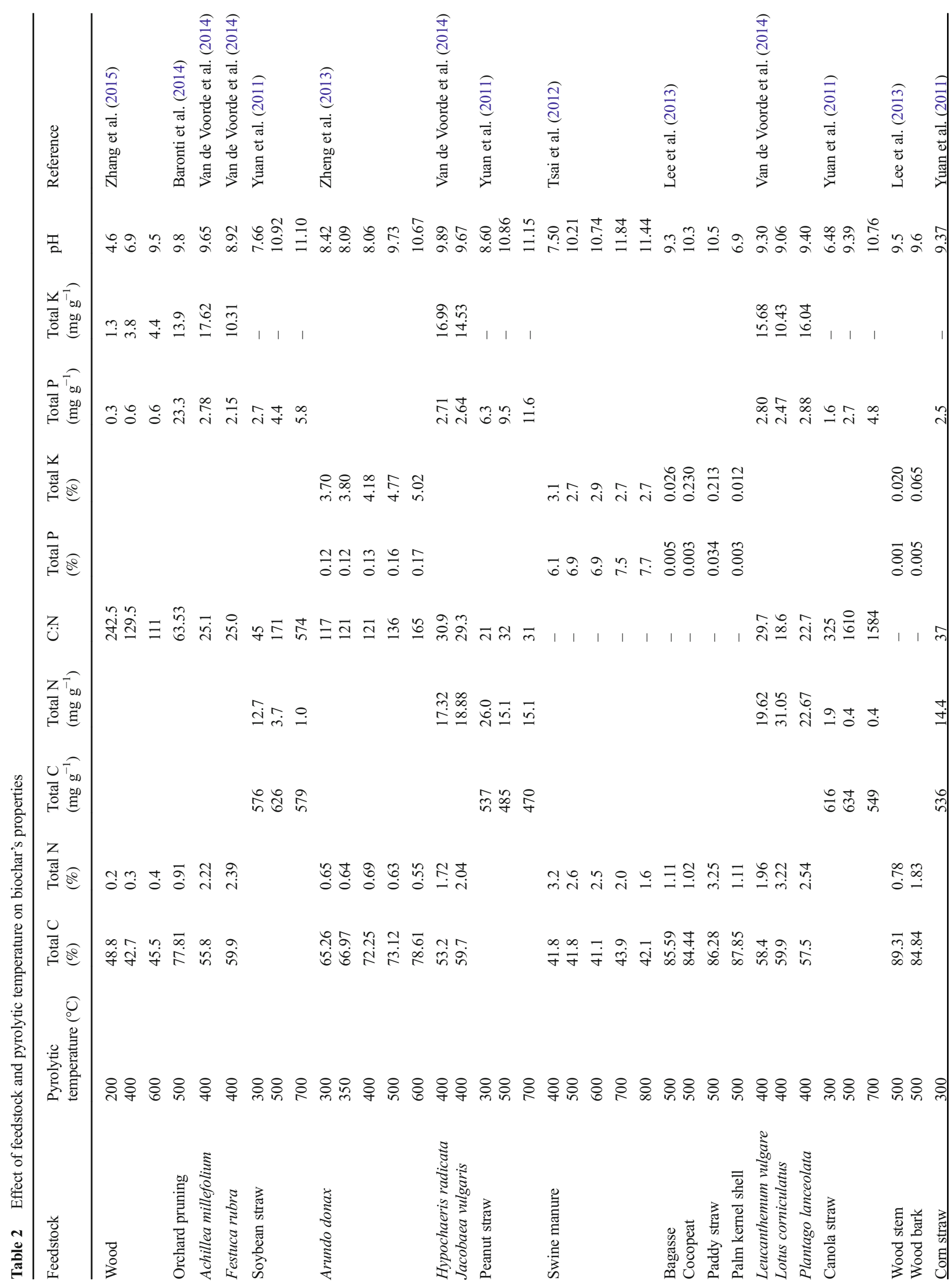




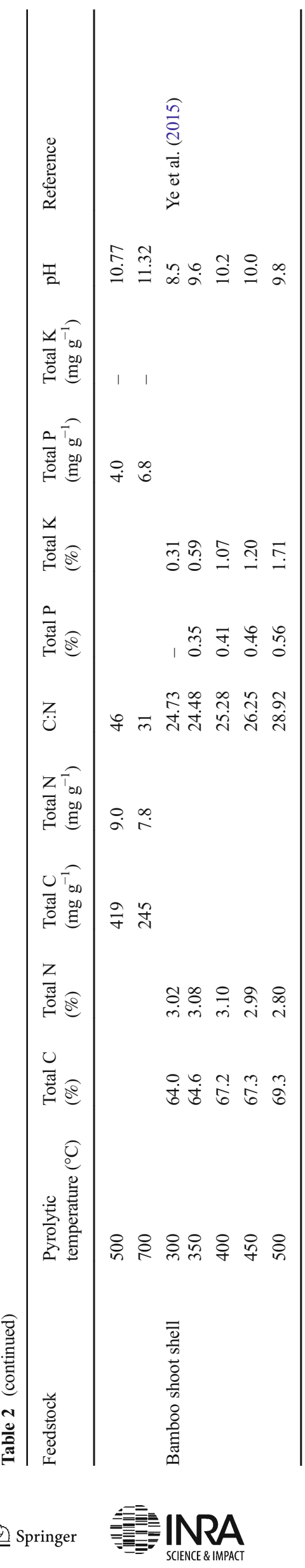

3 The influence of biochar on properties of soils

Currently, some studies have focused on the amendment of biochar on physical and chemical properties of various soils (Table 3). Biochar could possibly be part of a long-term adaptation strategy, as it could improve soil physical properties including the increase of porosity and water storage capacity, as well as the decrease of bulk density (Lu et al. 2014; Nelissen et al. 2015). Biochar may also be used as a sustainable amendment to enhance soil chemical properties (Lehmann et al. 2011; Glaser et al. 2002). For example, the content of ash in biochars ranged from 0.35 to $59.05 \%$, which were rich in available nutrients, especially cationic elements, such as $\mathrm{K}\left(0-560 \mathrm{mmol} \mathrm{kg}^{-1}\right), \mathrm{Ca}\left(3-1210 \mathrm{mmol} \mathrm{kg}^{-1}\right), \mathrm{Mg}$ $\left(0-325 \mathrm{mmol} \mathrm{kg}{ }^{-1}\right)$, and $\mathrm{Na}\left(0-413 \mathrm{mmol} \mathrm{kg}{ }^{-1}\right)$ (Rajkovich et al. 2012). Similarly, Yuan et al. (2011) reported that the content of soluble base cations $\left(\mathrm{K}^{+}, \mathrm{Ca}^{2+}, \mathrm{Mg}^{2+}\right.$, and $\left.\mathrm{Na}^{+}\right)$ ranged from 48 to $330 \mathrm{cmol} \mathrm{kg}^{-1}$. Moreover, ash content could increase soil $\mathrm{pH}$ which may determine cation exchange capacity of various charged soils (Sollins et al. 1988) and nutrient availability (Mengel and Kirkby 2001). Actually, besides the direct amendment of biochar on soil's properties, biochar can also alter microbial and nutritional status of the soil within the plant rooting zone through changing soil physical properties (e.g., bulk density, porosity, and particle size distribution). Overall, the improvement of soil properties is highly contributed to the increased of both nutrient and water use efficiency and crop productivity.

\subsection{The effect of biochar on physical and chemical properties of soils}

The physical and chemical properties of biochar are keys to understand performances and mechanisms of biochar in the improvement of soil's fertility. A possible main mechanism for yield improvement may be the increase of soil water holding capacity after biochar treatment (Jeffery et al. 2011). Biochar has high total porosity, and it could both retain water in small pores and thus increase water holding capacity and assist water to infiltrate from the ground surface to the topsoil through the larger pores after heavy rain (Asai et al. 2009). Peake et al. (2014) indicated that biochar application could increase available water capacity by over $22 \%$. Nelissen et al. (2015) demonstrated that biochar application could increase available water capacity from 0.12 to $0.13 \mathrm{~m}^{3} \mathrm{~m}^{-3}$. Moreover, the formation and stability of soil aggregates could increase the crop production and the prevention of soil degradation (Amezketa 1999). The capacity of soil aggregation increased ranging from 8 to $36 \%$ after the application of rice husk biochar ( $\mathrm{Lu}$ et al. 2014). They also reported that the application of rice husk biochar application could increase soil pore structure parameters by $20 \%$ and shear strength, as well as decrease soil swelling by $11.1 \%$ (Lu et al. 2014). In 


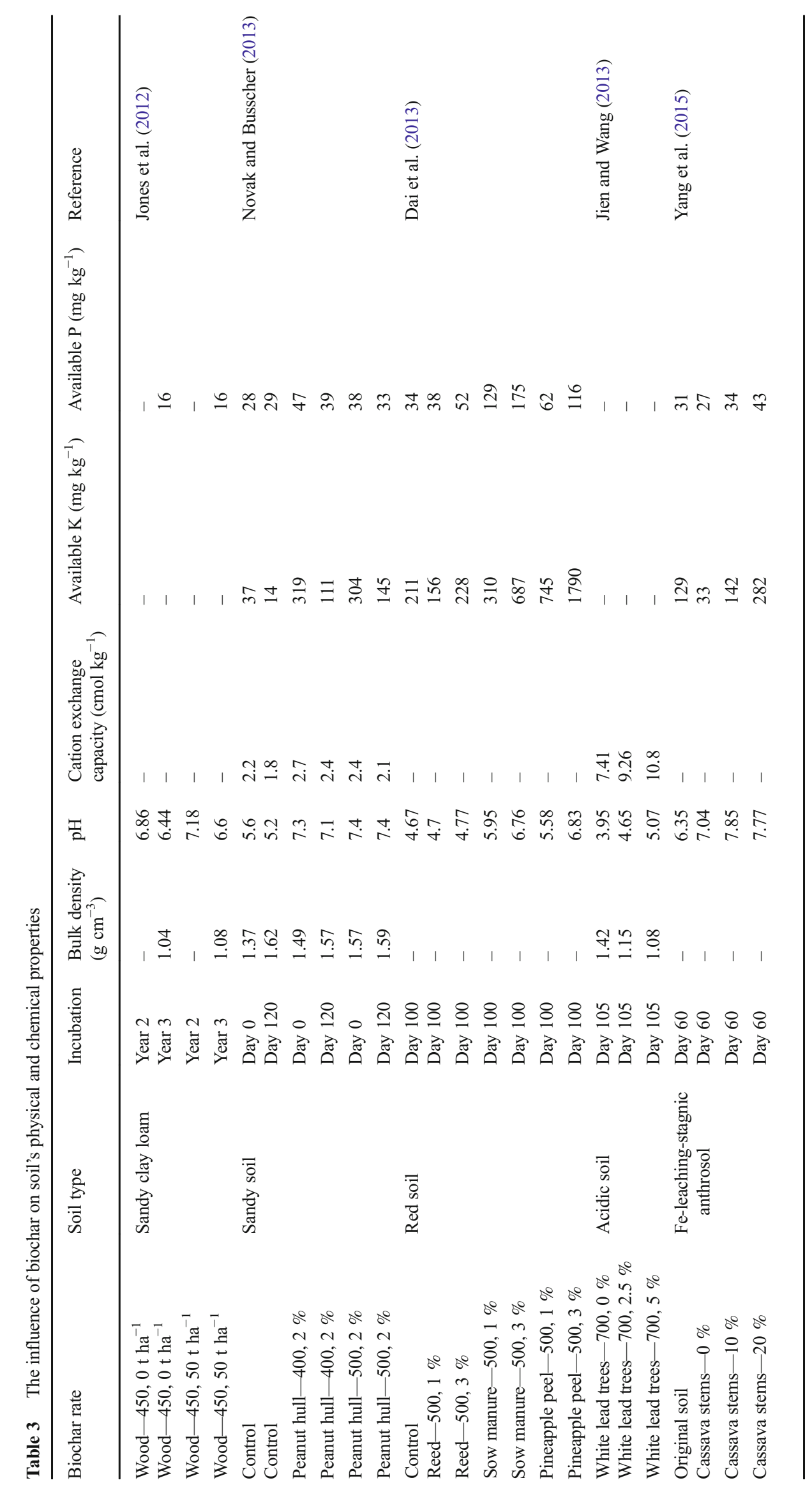


addition, biochar could ameliorate compaction by over $10 \%$ (Peake et al. 2014), decrease bulk density from 1.47 to $1.44 \mathrm{mg} \mathrm{m}^{-3}$, and increase porosity from 0.43 to $0.44 \mathrm{~m}^{3} \mathrm{~m}^{-3}$ (Nelissen et al. 2015). Overall, the improved physical properties of soil, such as bulk density, water holding capacity, and aggregation ability, may increase the retention of both water and nutrients, which benefit to soil fertility directly.

The application of biochar could increase soil $\mathrm{pH}$ value. Wang et al. (2014) reported that rice husk biochar increased the tea garden soil (acid soil) pH from 3.33 to 3.63. The agricultural soil $\mathrm{pH}$ increased by almost $1 \mathrm{pH}$ unit for biochar treatment which produced from mixed hardwood (Quercus spp. and Carya spp.) (Laird et al. 2010). The increase of soil $\mathrm{pH}$ could change the form of nutrients and facilitate some elements adsorption of the root. Cation exchange capacity is indirect measures of the capacity of soils to retain water and nutrients. Laird et al. (2010) indicated that the biochar treatments significantly increased cation exchange capacity by 4 to $30 \%$ and relative to the controls. Similarly, cation exchange capacity of the highly weathered soil was increased from 7.41 to $10.8 \mathrm{cmol} \mathrm{kg}^{-1}$ after biochar treatment, which produced from Leucaena leucocephala (Jien and Wang 2013). Moreover, the increase in the amount of exchangeable cations in the amended soils suggested an improvement in soil fertility and nutrient retention, which may be attributed to the high specific surface area and a number of carboxylic groups of the biochar (Cheng et al. 2006). The amounts of the extractable nutrient elements (e.g., $\mathrm{Na}, \mathrm{K}, \mathrm{Ca}$, and $\mathrm{Mg}$ ) could be increased after biochar application. Wang et al. (2014) indicated that the amounts of the extractable $\mathrm{K}, \mathrm{Ca}, \mathrm{Na}$, and $\mathrm{Mg}$ approximately increased by ranging from 60 to $670 \%$ after biochar addition. For example, the $\mathrm{K}$ content of soil increased from 42 to $324 \mathrm{mg} \mathrm{kg}^{-1}$ (Wang et al. 2014). In addition, biochar treatment could increase base saturation percentage from 6.4 to $26 \%$ and saturated hydraulic conductivity from 16.7 to $33.1 \mathrm{~cm} \mathrm{~h}^{-1}$, decrease soil erosion rate from 1458 to $532 \mathrm{~g} \mathrm{~m}^{-2} \mathrm{~h}^{-1}$ (Jien and Wang 2013), and increase total C from 2.27 to $2.78 \%$ and total $\mathrm{N}$ from 0.24 to $0.25 \%$ and available $\mathrm{P}$ from 15.7 to $15.8 \mathrm{mg} \mathrm{kg}^{-1}$ (Jones et al. 2012). These improvements in soil chemical properties could increase soil fertility by increasing the nutrient contents and availability.

However, changes of soil physical or chemical properties were not always detected. For instance, Jones et al. (2012) indicated that soil electrical conductivity (from 46 to $43 \mu \mathrm{S} \mathrm{cm}^{-1}$ ) and bulk density (from 1.04 to $1.08 \mathrm{~g} \mathrm{~cm}^{-1}$ ) were not significantly influenced after 3 years of biochar addition in a UK field trial. Even the same experiment, in the first year application of biochar, it seems to ameliorate soil physical quality to some extent, including increasing porosity, decreasing soil bulk density, and improving soil aggregation (Nelissen et al. 2015). However, Nelissen et al. (2015) did not observe the difference between hydraulic conductivity and plant available water capacity in the second year after biochar application. Additionally, over 2 years, biochar application did not have a significant impact on soil chemical properties, except for organic carbon content and C: $\mathrm{N}$ ratios (Nelissen et al. 2015). These results suggested that the influences of biochar on soil physical and chemical properties are varied with different application conditions. Long-term field trials need to be conducted to test whether soil properties can be influenced permanently through biochar application. Overall, the improvements of soil properties could directly or indirectly increase nutrient contents and availability and decrease nutrient leaching, which are known as mechanisms for the increase of soil fertility.

\subsection{Influencing factors of biochar function}

Some factors are needed to be considered for the application of biochar into the soil. The improvement of nutrient availability is dependent on the increase of soil $\mathrm{pH}$ caused by biochar addition, especially $\mathrm{P}$ and $\mathrm{K}$ (Atkinson et al. 2010). Deenik et al. (2010) and Spokas et al. (2011) indicated that biochar with high volatile matter content, which produced at higher temperature, contributed to $\mathrm{N}$ immobilization and microbial activity reduction which could inhibit plant growth. It is possible that the effects of biochar amendment depend on soil properties, especially soil texture and mineralogy. Moreover, (Peake et al. 2014) reported that the effect of biochar on field capacity and available water capacity varied across different soil types, and these effects were modified slightly but significantly in relation to specific soil properties. Furthermore, different biochar application rates were recommended for various texture soils because of the difference of soils' buffering capacity (Butnan et al. 2015). They indicated that the low application rate (1\%) of Thai traditional kiln biochar made from Eucalyptus camaldulensis was appropriate for the coarse-textured soil, which had low buffering capacity. However, the higher rate (2\%) of biochar was recommended for fine textured soil, which had higher buffering capacity compared to coarse-textured soil. Besides, Jones et al. (2012) demonstrated that biochar had no effect on the growth of maize but did enhance the growth and nutritional quality of the subsequent grass crop. The possible reason may be the differences in rooting depth. These aspects indicated that biochar function was highly related to pyrolysis temperatures, soil and plant types, and application rates. It is crucial to understand the underlying influencing factors of biochar function for choosing the optimum biochar for each particular soil, both maximizing soil productivity and minimizing deleterious environmental effects. 


\section{Adsorption and release of nutrients from biochar}

\subsection{Adsorption of nutrients and application as slow-release fertilizer}

Many studies showed that biochar had the potential to sorb nutrients. Nitrate adsorption capacity of biochar produced from bamboo at $900{ }^{\circ} \mathrm{C}$ was approximately $1.2 \mathrm{mg} \mathrm{g}^{-1}$, which was relatively higher than that of activated carbon (about $0.9 \mathrm{mg} \mathrm{g}^{-1}$ ) (Mizuta et al. 2004). Yao et al. (2012) indicated that biochars could effectively sorb nitrate by $3.7 \%$, ammonium by $15.7 \%$, and phosphate by $3.1 \%$. However, the adsorption capacity of nutrient may be greatly influenced by biochar's properties, including $\mathrm{pH}$, surface acidic groups, and ion exchange capacity (Yao et al. 2012; Morales et al. 2013). Therefore, it is crucial to understand the underlying mechanisms of nutrient sorption. The mechanisms describing the adsorption capacity of polar and apolar compounds are attributed to chemisorption, including hydrophobic bonding (Zhang et al. 2013), $\pi-\pi$ electron donor-acceptor interactions resulting from fused aromatic carbon structures (Swiatkowski et al. 2004), and weak unconventional H-bonds (Conte et al. 2013). For example, the mechanisms attributed to adsorption of $\mathrm{NH}_{4}{ }^{+}$onto biochar surfaces include physical adsorption (van der Waals adsorption) (Zhang et al. 2015), $\mathrm{NH}_{4}{ }^{+}$attraction to negatively charged surfaces (Zheng et al. 2013), $\mathrm{NH}_{4}{ }^{+}$ reacting with acidic functional groups to form amides and amines (Spokas et al. 2012), $\mathrm{NH}_{4}{ }^{+}$binding to cationic species sites on the surface of biochars (Hale et al. 2013), and $\pi-\pi$ electron donor-acceptor interactions (Zhu and Pignatello 2005). Dissimilarly, biochar could not independently sorb the added P. Biochar affected $\mathrm{P}$ availability by interaction with other organic and inorganic components in the soil, including organic matter or other base cations in the soil (Xu et al. 2014).

Though there were little field trials focused on the study of biochar as slow-release fertilizer, many laboratory studies investigated the nutrients availability with biochar application. A clearer understanding of not only sorption but also desorption is indispensable because they are the processes that along with nutrients mineralization, controlling soil solution nutrients concentration, enhancing nutrients bioavailability. The influencing factors, which affect nutrients desorption, such as soil types, feedstocks, pyrolysis conditions, and biochar application rates, are needed to be considered. In the black soil, the average percentage of desorbed $\mathrm{P}$ were $36,37,39$, and $41 \%$ for the $0,1,5$, and $10 \%$ biochar application rates, respectively (Xu et al. 2014). Moreover, differences of $\mathrm{P}$ desorption were presented among black soil $\left(24.6 \mathrm{mg} \mathrm{kg}^{-1}\right)$, brown soil $\left(82.5 \mathrm{mg} \mathrm{kg}^{-1}\right)$, and fluvo-aquic soil $\left(27.7 \mathrm{mg} \mathrm{kg}^{-1}\right)$ when the biochar application rates and $\mathrm{P}$ loading were $10 \%$ and $240 \mathrm{mg} \mathrm{L}^{-1}$ (Xu et al. 2014). Ingá biochar made by slow pyrolysis at 400,500 , and $600{ }^{\circ} \mathrm{C}$ could release $\mathrm{P}$ by 32,28 , and $69 \mathrm{mg} \mathrm{kg}^{-1}$, respectively. Moreover, they indicated that Ingá biochar could desorb P by
$75 \mathrm{mg} \mathrm{kg}^{-1}$ in the first step, while Embaúba biochar could desorb P by $310 \mathrm{mg} \mathrm{kg}^{-1}$ and Lacre biochar could desorb P by $258 \mathrm{mg} \mathrm{kg}^{-1}$ (Morales et al. 2013). In addition, Zhang et al. (2015) demonstrated that desorption of $\mathrm{NH}_{4}{ }^{+}$in biochars was greater than activated biochars which ranged from $18 \%$ for biochar (made at $600{ }^{\circ} \mathrm{C}$ ) at $2.7 \mathrm{mg} \mathrm{L}^{-1}$ to $31 \%$ for biochar (made at $450{ }^{\circ} \mathrm{C}$ ) at $5.1 \mathrm{mg} \mathrm{L}^{-1}$. Desorption of $\mathrm{NO}_{3}{ }^{-}$in activated biochar treatment (4-5 $\mathrm{mg} \mathrm{L}^{-1}$ ) was higher than that of biochars (0-4 $\left.\mathrm{mg} \mathrm{L}^{-1}\right)$ (Zhang et al. 2015). These phenomena may be induced by the differences of the soil $\mathrm{pH}$ and the activity or availability of cations $\left(\mathrm{Al}^{3+}, \mathrm{Fe}^{3+}\right.$, and $\mathrm{Ca}^{2+}$ ) that interact with nutrients in biochars. Therefore, biochar has great potential as slow-release fertilizer. In order to better manage soil nutrients for maximum bioavailability, further investigation should focus on the methods which can measure nutrients availability of desorbed nutrients from biochar or soil, such as isotope analysis.

\subsection{The retention of soil nutrients by biochar}

Some researches indicated that incorporation of biochar into soil effectively reduced $\mathrm{N}_{2} \mathrm{O}$ emission from different soils. For instance, Rondon et al. (2005) reported that $50 \%$ reduction of $\mathrm{N}_{2} \mathrm{O}$ emissions was found under soybean systems while $80 \%$ decrease of $\mathrm{N}_{2} \mathrm{O}$ emissions was found for grass systems. Similarly, biochars treatment could decrease $\mathrm{N}_{2} \mathrm{O}$ emissions from 1768 to $45-699 \mu \mathrm{g} \mathrm{N} \mathrm{N}_{2} \mathrm{O}-\mathrm{N} \mathrm{m}^{-2} \mathrm{~h}^{-1}$ (Wang et al. 2013) and suppress $\mathrm{N}_{2} \mathrm{O}$ emissions between 21.3 and $91.6 \%$ (Stewart et al. 2012). However, there were several studies reported that no effect (Cheng et al. 2012) or even increase (Clough et al. 2010) was detected on $\mathrm{N}_{2} \mathrm{O}$ emissions after the application of biochar. The retention of nutrients by biochar could be dependent on biochar pyrolysis temperature, soil types, fertilizer doses, and soil water contents.

Biochar's chemical and physical properties are greatly dependent on pyrolytic temperatures, and then the adsorption of nutrients would be influenced by biochar application. The reduced $\mathrm{N}_{2} \mathrm{O}$ emissions is attributed to the content of polycyclic aromatic hydrocarbons in the low-temperature biochars $\left(300-400{ }^{\circ} \mathrm{C}\right.$ ), but not in the high-temperature biochars $\left(>500{ }^{\circ} \mathrm{C}\right.$ ), while biochars produced at $200{ }^{\circ} \mathrm{C}$ contained a relatively large amount of phenolic compounds and markedly reduced $\mathrm{N}_{2} \mathrm{O}$ emission (Wang et al. 2013). The potential explanations for the effects of pyrolysis temperature on nutrients' immobilization have mainly focused on dissimilarities of biochar's volatile compounds, surface area, and porosity (Azargohar and Dalai 2008).

Feedstocks, biochar application rates, fertilizer, and soil types should also be considered as noticeable factors for changing stabilization of nutrients. Nelissen et al. (2014) reported that $\mathrm{N}_{2} \mathrm{O}$ emission approximately decreased by ranging from 60 to $90 \%$ and NO emission approximately decreased by ranging from 30 to $90 \%$ after biochars treatment, which were produced from willow, pine, and maize. Moreover, the cumulative $\mathrm{N}_{2} \mathrm{O}-\mathrm{N}$ 
emissions could be decreased by ranging from 53.9 to $83.5 \%$ for the biochars applications ranging from 1 to $20 \%$, respectively (Stewart et al. 2012). Besides, when urea and fertilizers were applied, $\mathrm{N}_{2} \mathrm{O}$ emissions were decreased in all biochar treatments compared to the control with an average of $53 \%$ (from 618 to $295 \mu \mathrm{g} \mathrm{N} \mathrm{kg}^{-1}$ ) and $84 \%$ (from 3356 to $529 \mu \mathrm{g} \mathrm{N} \mathrm{kg}^{-1}$ ), respectively (Nelissen et al. 2014). These results demonstrated that the influence of fertilizer types on nutrients' fixing cannot be neglected. Soil types should be considered as another influencing factor on immobilization of nutrients. For instance, (Rondon et al. 2005) reported that biochar decreased $\mathrm{N}_{2} \mathrm{O}$ emissions by 50 and $80 \%$ under soybean and grass systems, respectively. Nevertheless, the application of biochar was not absolute to reduce the loss of nutrients. For example, Scheer et al. (2011) reported that the cattle feedlot waste biochar had no significant effect on $\mathrm{N}_{2} \mathrm{O}$ emission from red Ferrosol. Similarly, Clough et al. (2010) also documented that fluxes of $\mathrm{N}_{2} \mathrm{O}$ from the biochar plus urine treatment were higher, compared to urine alone during the first 30 days, but there was no significant difference after 50 days. Consequently, in order to choose suitable biochar types for various soil types, it is significant to clear the potential mechanisms which should be responsible for the immobilization of nutrients.

Recently, abiotic interactions in the biochar-amended soils is ascribed to the potential explanations or mechanisms for the $\mathrm{N}_{2} \mathrm{O}$ mitigation, including changes of $\mathrm{pH}$, water penetration and decrease of bulk density, improvement of nutrients availability and soil structure, and increase of sorption capacity (Spokas et al. 2009; Singh et al. 2010; Taghizadeh-Toosi et al. 2011, 2012). Nelissen et al. (2014) hypothesized that the most likely mechanisms reducing $\mathrm{NO}$ emissions included the following parts: (i) stimulated $\mathrm{NH}_{3}$ volatilization, (ii) biotic $\mathrm{N}$ immobilization, and (iii) non-electrostatic sorption of $\mathrm{NH}_{4}{ }^{+}$. The underlying mechanism that ammonia could be used as nutrient is likely the reversibility of ammonia trapping through the formation of ammonium salts (Taghizadeh-Toosi et al. 2011). Therefore, biochar may store nutrients and be used as slow-release fertilizer. However, the main mechanisms underlying the enhancement of nutrients availability with biochar application deserve further determination in order to improve the qualities of agriculture soils.

\section{Biochar, microorganisms, and fertility}

Biochar has been shown not only to improve soil physicochemical properties but also to change soil biological properties (Pietikäinen et al. 2000; Lehmann et al. 2006; Kim et al. 2007; O'neill et al. 2009; Grossman et al. 2010; Liang et al. 2010). These changes could ameliorate soil structure, containing increasing organic/mineral complexes (aggregates) and pore spaces (Rillig and Mummey 2006), enhance nutrient cycles, which include the increase of nutrient retention and immobilization, as well as the decrease of nutrient leaching (Steiner et al. 2008b), thus promote plant growth (Warnock et al. 2007). Besides, microorganisms, such as rhizosphere bacteria and fungi, may facilitate plant growth directly (Schwartz et al. 2006; Compant et al. 2010). In summary, changes in microbial community composition or activity induced by biochar may affect nutrient cycles and plant growth, as well as the cycling of soil organic matter (Wardle et al. 2008; Kuzyakov et al. 2009; Liang et al. 2010). This section gives an overview of the influence of biochar properties, such as organic and inorganic composition or surface properties, on microbial community.

\subsection{Influence of biochar on microorganisms community}

There are growing interests in the application of biochar as a means to manage soil biota, and small changes of soil biota induced by biochar application are of equally strong concern. Some mechanisms may explain how biochar could affect microorganisms in soils: (1) changes in nutrient availability; (2) changes in other microbial communities; (3) alterations in plant-microbe signaling; and (4) habitat formation and refuge from hyphal grazers. Microbial properties are largely affected by the soil food web. Furthermore, the trophic structure of the soil food web highly depended on the quantity, quality, and distribution of organic matter. Despite the slow rates of production of soil organic matter compared with other flows in the carbon cycles, its relative stability for microbial decomposition facilitates soil organic matter accumulation.

\subsubsection{Influence of biochar on microbial abundance}

Domene et al. (2014) indicated that microbial abundance could increase from 366.1 (control) to $730.5 \mu \mathrm{g} \mathrm{C} \mathrm{g}^{-1}$ after an addition of $30 \mathrm{t} \mathrm{ha}^{-1}$ biochar. Similarly, microbial abundance increased by 5-56\% with the increase of corn stover biochar rates (from 0 to $14 \%$ ) for the different preincubation times (2-61 days) (Domene et al. 2015). Some possible reasons may be responsible for the increase of microbial abundance, such as higher availability of nutrients or labile organic matter on biochar surface (Pietikäinen et al. 2000; Bruun et al. 2012), less competition (Lehmann et al. 2011), the enhanced habitat suitability and refuge (Pietikäinen et al. 2000; Warnock et al. 2007), the increased water retention and aeration (Wardle et al. 1999; Schimel et al. 2007), or positive priming (Zimmerman et al. 2011).

Furthermore, nutrient and carbon availability can affect microbial abundance. This influence was greatly varied with the different types of biochar and the special microorganisms group. It can be considered that symbiotic relationships with biota through changing nutrient supplies were formed from the different demands of the plant. Similar explanations may 
hold for the effect of $\mathrm{C}$ supply increasing by exudation or root turnover in the rhizosphere and $\mathrm{C}$ as energy sources for heterotrophic microorganisms (Lehmann et al. 2011). Consequently, the influence on microbial abundance was dissimilar with the different sphere of biochar additions, including rhizosphere and bulk soil. On the other hand, under nutrient-limiting conditions, microbial abundance may be increased due to the greater nutrient availability after biochar application (Taylor 1951). The possible reasons were biochar-driven improvements in nutrient retention or the release of nutrient by the biochar (Lehmann et al. 2011). Some recent researches seem to demonstrate that the following aspects can dominate the influence of nutrient and $\mathrm{C}$ availability on microbial biomass, (i) the existing nutrient and $\mathrm{C}$ availability in soil; (ii) the additive amount of nutrient and $\mathrm{C}$; and (iii) the properties of microorganisms.

The $\mathrm{pH}$ of soils may change, after biochar additions, because of the acidity or basicity of biochar. Different living conditions will be formed for microorganisms with different $\mathrm{pH}$ of biochar. For example, Aciego Pietry and Brookes (2008) indicated that microbial biomass $\mathrm{C}$ increased from about 20 to $180 \mu \mathrm{g}$ biomass $\mathrm{C} \mathrm{g}^{-1}$ soil and microbial biomass ninhydrin-N increased from about 0.5 to $4.5 \mu \mathrm{g}$ ninhydrin$\mathrm{N} \mathrm{g}^{-1}$ soil with rising $\mathrm{pH}$ values from 3.7 to 8.3 under otherwise identical environmental conditions, which demonstrated that the rising soil $\mathrm{pH}$ could increase microbial biomass. Moreover, there are different influences on different microbial abundance if $\mathrm{pH}$ values are changed. With the increase of $\mathrm{pH}$ up to values around 7, bacterial populations were possible to increase, whereas, no change in fungi abundance was observed (Rousk et al. 2010). Similar to nutrient and C changes, the pre-existing soil $\mathrm{pH}$, the direction, and magnitude of change will also largely affect the level of $\mathrm{pH}$ changes.

Microbial abundance could be increased after microorganisms sorb to biochar surfaces, which render them less susceptible to leaching in soil. Hydrophobic attraction, electrostatic forces, and precipitates forming are involved in the main processes of adsorption to biochar (George and Davies 1988). Moreover, biochar, containing a well-developed pore structure, may provide living environment for microorganisms. Both bacteria and fungi are hypothesized to be better protected against predators or competitors by exploring pore habitats in biochar (Ezawa et al. 2002; Saito and Marumoto 2002; Thies and Rillig 2009).

Biochar could be used to sorb toxins and chemical signals which would hinder microbial growth. Pollock (1947) indicated that biochar could arrest the growth-inhibiting substances. Furthermore, high-temperature biochars have been found to have a stronger adsorption on compounds that are toxic to microorganisms (Chen et al. 2009; Kasozi et al. 2010). Additionally, the humidity may influence largely on microbial abundance. Microorganisms would be stressful in soil of periodic drying which may induce the dormant or even dead
(Schimel et al. 2007). Biochar has great water holding capacity because of the large surface area, which could promote the growth of microorganisms. However, further conclusions cannot be obtained only from the original materials and properties of biochar. There is a speculation that bacterial cells or growth-regulating compounds may play an important role in sorption.

\subsubsection{Influence of biochar on microbial composition and structure}

Addition of biochar may cause some changes in microbial community composition and structure; thus, trophic relationships are likely to be changed. Prayogo et al. (2014) used canonical variate analysis to examine the effect of treatment on the structure of microbial community. They indicated that the first canonical variate analysis axis accounting for $75.5 \%$ of the variance and the second axis representing $24.6 \%$ of the variation, which suggested a significant changes in microbial community structure after biochar application. Biochar would be expected to cause a shift in the fungus: bacteria ratio, since fungi could be better placed to degrade lignin contained within biochar. Furthermore, changes in microbial community composition may be associated in some shifts in $\mathrm{pH}$ induced by the application of biochar (Prayogo et al. 2014). Nevertheless, few researches have focused on the biological significance of the shift in $\mathrm{pH}$ induced by biochar. Besides, the diversity of microorganisms could be increased or decrease after addition of biochar to soil. For instance, bacterial diversity was increased by as much as $25 \%$ in biochar-rich Terra preta soils compared to unmodified soils in both culture-independent (Kim et al. 2007) and culture-dependent (O’Neill et al. 2009) studies. However, compared to the unmodified soils, lower diversity of archaea (Taketani and Tsai 2010) and fungi (Jin 2010) were found in Terra preta and a biochar-amended temperate soil, respectively. This information indicates that different microbial groups respond in different ways after biochar application into soil.

\subsection{Influence of biochar on microbial activity}

In agroecosystems, decomposer microorganisms could enhance nutrient release from soil organic matter to the rhizosphere of crop, which are essential for the inputs of nutrients and the sustainable crop production (Bardgett 2005). There are some indexes, such as different enzymes and metabolism rates, which can be used as means to assess the soil biological activity. With the increase of biological activities and community shifts, the retention of $\mathrm{N}$ and $\mathrm{P}$ were enhanced (Pietikäinen et al. 2000; Thies and Rillig 2009; Lehmann et al. 2011); thus, these processes may increase plant nutrient availability in nutrient-limited agroecosystems (Major et al. 2010). With application of chicken manure biochar from 0 
to $15 \%$, soil dehydrogenase activity increased from 2.75 to $8.96 \mathrm{mg} \mathrm{TPF} \mathrm{kg}^{-1} 24 \mathrm{~h}^{-1}$ (Park et al. 2011). Paz-Ferreiro et al. (2012) indicated that, compared to the control, phosphomonoesterase increased by $70.8 \%$ after the treatment of sewage sludge biochar at a rate of $4 \%$. Possibly, the increases of organic $\mathrm{N}$ - and P-mineralizing enzymes are attributed to the plant uptake of $\mathrm{N}$ and $\mathrm{P}$ and growth of fine roots as well as hairs into biochar pores. However, Domene et al. (2014) found that no significant changes in microbial activity, when measured as basal respiration and feeding rates, indicated that net microbial processing of organic $\mathrm{C}$ did not change with application of biochar but rather with differences in soil texture. This result was in agreement with other long-term studies under field conditions were no change or even lower respiration rates (Woolf and Lehmann 2012). Therefore, it is possible that the increased microbial activity highly rely on the easily mineralizable organic content of fresh biochars.

\subsection{Impact of biochar on functional ecology of microorganisms}

Additions of biochar may either increase or decrease many soil processes, such as $\mathrm{C}$ mineralization (Kuzyakov et al. 2009; Liang et al. 2010), denitrification and methane oxidation (Yanai et al. 2007; Van Zwieten et al. 2009), and nutrient transformations (Deluca et al. 2009). Numerous reasons may be responsible for these effects, such as altered $\mathrm{C}$ sources or nutrient availability and sorption of inorganic and organic compound. Moreover, various enzymes activity, different water retention and infiltration properties or changes in pore architecture may have effects on microbial functional ecology. In other words, alterations of soil processes could be considered as a result of the changes of microbial community structure, abundance, activity, and metabolism.

The mineralization or oxidation of biochar itself will be influenced by the changes of microbial properties. However, these soil processes depend on some aspects, including the amounts of available $\mathrm{C}$ sources, the sorption of organic $\mathrm{C}$ of easy degradation, the existing of stable biochar, or the effect of $\mathrm{pH}$ and phenolic materials on microbial community. For instance, non-pyrolyzed $\mathrm{C}$ rather than labile $\mathrm{C}$ additions could enhance the mineralization of biochar (Liang et al. 2010). What is more, changes in microbial community caused by biochar additions may also increase mineralization of other soil C. Wardle et al. (2008) found that a greater decomposition of soil $\mathrm{C}$ was generated by greater microbial biomass in the presence of biochar. However, this has generally not been observed beyond an initial greater mineralization after fresh biochar additions (Hamer et al. 2004; Wardle et al. 2008; Zimmerman et al. 2011), indicating that various reasons of $\mathrm{C}$ loss could be converted into physical export of $\mathrm{C}$, changes in pH or nutrient contents (Lehmann and Sohi 2008). Therefore, biochar mineralization may depend on the proportion of labile $\mathrm{C}$ and the nutrient contents in the biochar.

Additionally, biochar may facilitate the microbially mediated transformation of nutrients in soil. Ball et al. (2010) reported that nitrification was increased by biochar additions to forest soil and explained by sorption of phenolics that would otherwise inhibit nitrification and an increase in ammoniaoxidizing bacteria (Deluca et al. 2006). Additionally, Bailey et al. (2010) found that activity of alkaline phosphatase, aminopeptidase, and $\mathrm{N}$-acetylglucosaminidase increased with biochar application. The possible reason was that plant uptake of $\mathrm{N}$ and $\mathrm{P}$, and growth of fine roots and root hairs into biochar pores stimulated the production of organic $\mathrm{N}$ - and $\mathrm{P}$ mineralizing enzymes. The families of Bradyrhizobiaceae (Rhodoblastus, Rhodopseudomonas, Bradyrhizobium, and Nitrobacter) and Hyphomicrobiaceae (Rhodoplanes, Starkeya), which can utilize $\mathrm{N}_{2}, \mathrm{NO}_{3}{ }^{-}$, or $\mathrm{NH}_{3}$ through $\mathrm{N}_{2}$ fixing or denitrification, increased after biochar addition and were intimately involved in $\mathrm{C}$ and $\mathrm{N}$ cycling (Anderson et al. 2011). Moreover, microorganisms could generate ethylene in fresh biochar, which may be linked to the decreases of $\mathrm{N}_{2} \mathrm{O}$ and $\mathrm{CO}_{2}$ emissions (Spokas et al. 2010). Therefore, after biochar treatment, the improvements of microbial functional processes could decrease the emissions of gaseous nutrients, increase the retention of nutrients, and facilitate nutrients cycling.

\section{Negative effects of biochar on soil biota}

Negative, null, or positive effects of biochar on soil microbial community may depend on the biochar and soil type. Organic pyrolytic products, such as phenolics and polyphenolics, may be present in biochar and are harmful for soil microorganisms. Warnock et al. (2007) indicated that mycorrhizae and total microbial biomass decreased after biochar application. Gell et al. (2011) and Ennis et al. (2012) reported that the decrease in microbial abundance and activities might be also expected with an enhanced retention of toxic substances, such as heavy metals and pesticides, and the release of pollutants from biochar, such as bio-oil and polycyclic aromatic hydrocarbons. It is not valid to conclude that a special biochar which has positive effects on one soil biota would also have similar effects on others. For example, Rillig et al. (2010) reported that hydrochar could be beneficial to arbuscular mycorrhizae but may hinder plant growth. Several factors are likely to be responsible for the negative effects of biochar on soil biota, including the volatile matters, properties of biochar as well as salts, such as $\mathrm{Cl}$ or $\mathrm{Na}$. Turner (1955) reported withering of the petioles and discoloration of the leaves of clover plants after using biochar without washing procedures to remove organic and inorganic matters. Moreover, some biochars might pose a direct risk to soil biota and their functions 
(Liesch et al. 2010) and may explain some of the decreased crop yields reported in literatures. These may be short-term effects that need to be taken seriously in consideration and be evaluated for their suitability as a soil amendment.

\section{Discussions}

The performances and mechanisms of biochar in the improvement of soil fertility could be divided into four parts. Firstly, biochar could be used as a source of nutrients to increase soil fertility, due to the initial addition of soluble nutrients contained in the biochar and the mineralization of the labile fraction of biochar which contain organically bound nutrients. Moreover, the potential of biochar as nutrients source may mainly depend on the feedstock and pyrolysis temperatures. For instance, lower pyrolysis temperature may relatively increase the availability of $\mathrm{N}$ and $\mathrm{P}$, while higher pyrolysis temperature may relatively increase the availability of $\mathrm{K}$. Therefore, it is possible that biochar could be designed for specific end use. Secondly, biochar could improve soils' physical and chemical properties. Though the long-term experiments are still scarce, biochar could possibly be part of a long-term adaptation strategy. The main reason is that biochar could improve soils physical properties including the increase of porosity and water storage capacity. Actually, the improvements of soil properties (e.g., the increased aggregation capacity, $\mathrm{pH}$, and cation exchange capacity) could increase soil fertility by increasing nutrient contents and availability and decreasing nutrient leaching. Moreover, biochar properties, application conditions, and soil properties determine biochar function. Thirdly, biochar could store nutrients and be used as slow-release fertilizer. Due to biochar's specific properties (e.g., pore structure and functional groups), the surplus nutrients (e.g., nitrate, ammonium and phosphate) could be stored onto biochar surface. Subsequently, biochar could slowly release nutrients because of biochar's desorption properties, which may reduce nutrients leaching and increase nutrient contents. Moreover, biochar could increase soil fertility by reducing the $\mathrm{N}_{2} \mathrm{O}$ and $\mathrm{NO}$ emissions. Relatively, the lowtemperature biochars could be more efficient for reducing $\mathrm{N}_{2} \mathrm{O}$ emission. Fourthly, biochar could improve soil biological properties, including microbial abundance, structure, and activity. Biochar could improve microbial community by increasing nutrient availability, providing suitable shelter, and ameliorating living condition. The improved microbial community could facilitate nutrients cycling, which could decrease the emissions of gaseous nutrients and increase the retention of nutrients. In addition, biochar may have negative effects on microbial community, due to the harmful substances (e.g., phenolics and polyphenolics) contained in biochar.
The possible improvements of soil's properties and fertility after biochar application were shown in Fig. 3. On the one hand, the properties of soils, containing physical, chemical, and biological properties, could be improved after biochar treatment. Moreover, the improvement of soils properties is highly related to the specific physicochemical properties of biochar, such as high surface area, amount of functional groups, and the content of liming. For example, soil's cation exchange capacity may increase with the increase of carboxylic groups and surface area. The well-developed pore structure may not only enhance the capacity of water retention but
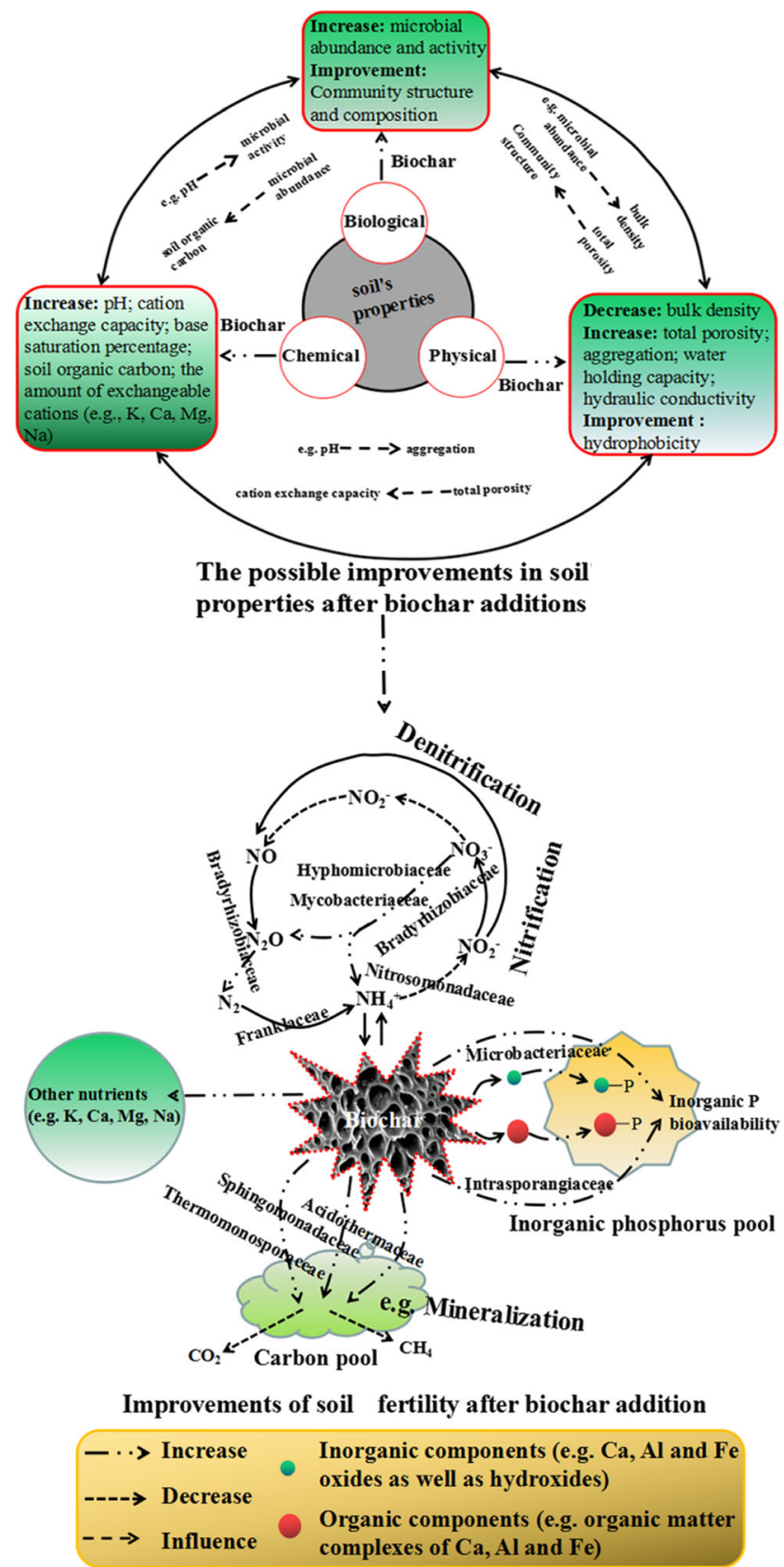

Fig. 3 The possible improvements of soil properties and fertility after biochar application 
also provide a shelter for soil's microorganisms, thus nutrient retention and cycling could be improved. The content of liming contained in biochar may increase soil's $\mathrm{pH}$ values. On the other hand, biochar could increase plant nutrient availability in soils by releasing nutrients, retaining nutrients, reducing nutrients leaching, and mitigating gaseous $\mathrm{N}$ losses. Therefore, biochar has great potential in the improvement of soil fertility.

The influencing factors should be considered before biochar application into soils. These factors could be divided into three aspects, including biochar properties, application conditions, and soil properties. Biochar properties are mainly dependent on the feedstocks and pyrolysis conditions especially temperature. For example, as shown in Table 2, manure biochar may contain more $\mathrm{P}$ content than biochar produced from other feedstocks. In general, the $\mathrm{pH}$ value may increase with the increase of pyrolysis temperature. Effects of the application conditions (e.g., application rate and time) on the soil properties were presented in Table 3. Actually, most laboratory and field studies were focused on the short-term effects of biochars on soil properties. The long-term experiments and studies are crucial for evaluating the benefits of biochar as a sustainable material. Soil properties are highly related to the soil type. For instance, highly weathered soils are typically characterized by strong acidity, low clay activity, and poor fertility and are considered to be degraded soils. Dissimilarly, vertisol is a soil containing a large amount of expansive clay minerals, and it has high swelling pressure, exceptionally low hydraulic conductivity, poor soil structure, and deep crack cutting when it is dry and stick when it is wet. Therefore, the main influencing factors should be analyzed and the maximum benefits should be evaluated before biochars application into soils.

Many researches showed that the application of biochar presents an ideal method to improve soils fertilizer. However, some fundamental mechanisms and the utilization of biochar in agro-ecosystem are poorly understood. These knowledge gaps mainly include the following aspects:

(i) It is significant to understand the interactions between biochar and soil microbial communities, which may critically affect the release of $\mathrm{CH}_{4}$ and $\mathrm{N}_{2} \mathrm{O}$ from soil, especially included nutrient biogeochemical cycles.

(ii) Understanding the dynamic mechanisms of biochar incorporation into soil. Biochar application is restricted by many factors, such as biochar and soil type and application rates. Thereby, to clear the role of each influencing factor played on the applying of biochar is inevitable for the process of field trials. In fact, the mechanisms and influencing factors are usually co-existence when biochar application into soil. The following researches should focus on the interactions between biochar, soil, microbes, and plant roots after biochar application into soil. (iii) The exact service life of biochar is still rarely understood. In other words, we should pay more attention to the decomposition rate of biochars in soil. Thus, we can choose biochar correctly and manage resources suitably.

(iv) The maximum adsorption and desorption capacity of biochar are needed to be determined in further researches. Biochars have indicated nonlinear adsorption and desorption of nutrients. With that in mind, the availability of mineral substance to plants and potential leaching of nutrient to the environment, which present in different biochars, are still unclear.

(v) Further studies should be focused on the combined application of several 'designed biochars' into soil. According to the main influencing factors and mechanisms, biochars could be produced purposefully. The combined application of several 'designed biochars' may increase the utilization efficiency of nutrients and manage soil specifically.

\section{Conclusions}

The application of biochar into soils has great potential for improving soils fertility and promoting plant growth. The choice of biochar managing various soils is flexible, because diverse biomass materials could be used as feedstocks of biochars and the feedstocks could be pyrolyzed at different temperatures. Moreover, biochar has huge surface area, welldeveloped pore structure, amounts of exchangeable cations and nutrient elements, and plenty of liming. Because of these properties, soil properties could be improved after biochar treatment. For instance, the huge surface area and welldeveloped pore structure may increase the water holding capacity and microbial abundance. The cation exchange capacity and availability of nutrients could be increased due to the amounts of exchangeable cations and nutrient elements. The increased $\mathrm{pH}$ of soils should be attributed to the plenty of liming contained in biochar. Therefore, improvements of soil physical, chemical, and biological properties promote the productivity of plant through increasing the amount of nutrient elements, enhancing availability of nutrient elements, reducing nutrient leaching, and mitigating gaseous nutrients losses.

These results of characterization analyses, column experiments and some field trials indicated that biochar could be designed or may have the potential to manage specific soil purposefully, through controlling the feedstock and pyrolysis conditions. Biochar can be a novel and feasible fertilizer directly or indirectly. This is not only because of the biochars' fertility but also their environmental and economic benefits. Despite the interests of using biochars to manage soils is increasing, some studies are also reported the negative effects and a number of research gaps as well as uncertainties still 
exist as discussed above in this review. In order to clear these knowledge gaps, further relevant investigations are inevitable in the following research, especially long-term experiments.

Acknowledgments This study was financially supported by the National Natural Science Foundation of China (Grant no. 41271332, 51478470, and 51521006).

\section{References}

Aciego Pietry JC, Brookes PC (2008) Relationships between soil pH and microbial properties in a UK arable soil. Soil Biol Biochem 40: 1856-1861. doi:10.1016/j.soilbio.2008.03.020

Amezketa E (1999) Soil aggregate stability: a review. J Sustain Agric 14: 83-151. doi:10.1300/J064v14n02-08

Anderson CR, Condron LM, Clough TJ, Fiers M, Stewart A, Hill RA, Sherlock RR (2011) Biochar induced soil microbial community change: implications for biogeochemical cycling of carbon, nitrogen and phosphorus. Pedobiologia 54:309-320. doi:10.1016/j.pedobi. 2011.07.005

Annabi M, Le Bissonnais Y, Le Villio-Poitrenaud M, Houot S (2011) Improvement of soil aggregate stability by reported applications of organic amendments to a cultivated silty loam soil. Agric Ecosyst Environ 144:382-389. doi:10.1016/j.agee.2011.07.005

Asai H, Samson BK, Stephan HM, Songyikhangsuthor K, Homma K, Kiyono Y, Inoue Y, Shiraiwa T, Horie T (2009) Biochar amendment techniques for upland rice production in Northern Laos, 1. Soil physical properties, leaf SPAD and grain yield. Field Crop Res 111:81-84. doi:10.1016/j.fcr.2008.10.008

Atkinson CJ, Fitzgerald JD, Hipps NA (2010) Potential mechanisms for achieving agricultural benefits from biochar applicaton to temperate soils: a review. Plant Soil 337:1-18. doi:10.1007/s11104-010-0464-5

Azargohar R, Dalai AK (2008) Steam and $\mathrm{KOH}$ activation of biochar: experimental and modeling studies. Microporous Mesoporous Mater 110:413-421. doi:10.1016/j.micromeso.2007.06.047

Baiamonte G, De Pasquale C, Marsala V, Cimò G, Alonzo G, Crescimanno G, Conte P (2015) Structure alteration of a sandyclay soil by biochar amendments. J Soils Sediments 15:816-824. doi:10.1007/s11368-014-0960-y

Bailey VL, Fansler SJ, Smith JL, Bolton JRH (2010) Reconciling apparent variability in effects of biochar amendment on soil enzyme activities by assay optimization. Soil Biol Biochem 43:296-301. doi: 10.1016/j.soilbio.2010.10.014

Ball PN, MacKenzie MD, DeLuca TH, Holben WE (2010) Wildfire and charcoal enhance nitrification and ammonium-oxidizing bacteria abundance in dry montane forest soils. J Environ Qual 39:12431253. doi:10.2134/jeq2009.0082

Bardgett R (2005) The biology of soil: a community and ecosystem approach. Oxford

Baronti S, Vaccari F, Miglietta F, Calzolari C, Lugato E, Orlandin S, Pini R, Zulian C, Genesio L (2014) Impact of biochar application on plant water relations in Vitis vinifera (L.). Eur J Agron 53:38-44. doi:10.1016/j.eja.2013.11.003

Bruun EW, Hauggaard-Nielsen H, Ibrahim N, Egsgaard H, Ambus P, Jensen PA, Dam-Johansen K (2011) Influence of fast pyrolysis temperature on biochar labile fraction and short-term carbon loss in a loamy soil. Biomass Bioenerg 35:1182-1189. doi:10.1016/j. biombioe.2010.12.008

Bruun EW, Ambus P, Egsgaard H, Haugaard-Nielsen H (2012) Effects of slow and fast pyrolysis biochar on soil $\mathrm{C}$ and $\mathrm{N}$ turnover dynamics. Soil Biol Biochem 46:73-79. doi:10.1016/j.soilbio.2011.11.019
Butnan S, Deenik JL, Toomsan B, Antal MJ, Vityakon P (2015) Biochar characteristics and application rates affecting corn growth and properties of soils contrasting in texture and mineralogy. Geoderma 237 : 105-116. doi:10.1016/j.geoderma.2014.08.010

Cantrell KB, Hunt PG, Uchimiya M, Novak JM, Ro KS (2012) Impact of pyrolysis temperature and manure source on physicochemical characteristics of biochar. Bioresour Technol 107:419-428. doi:10.1016/ j.biortech.2011.11.084

Cayuela ML, Sánchez-Monedero MA, Roig A, Hanley K, Enders A, Lehmann J (2013) Biochar and denitrification in soils: when, how much and why does biochar reduce $\mathrm{N}_{2} \mathrm{O}$ emissions? Sci Report 3: 17-32. doi:10.1038/srep01732

Chan KY, Van Zwieten L, Meszaros I, Downie A, Joseph S (2008a) Agronomic values of greenwaste biochar as a soil amendment. Soil Res 45:629-634. doi:10.1071/SR07109

Chan KY, Van Zwieten L, Meszaros I, Downie A, Joseph S (2008b) Using poultry litter biochars as soil amendments. Aust J Soil Res 46:437-444. doi:10.1071/SR08036

Chen H, Yao J, Wang F, Choi MMF, Bramanti E, Zaray G (2009) Study on the toxic effects of diphenol compounds on soil microbial activity by a combination of methods. J Hazard Mater 167:846-851. doi:10. 1016/j.jhazmat.2009.01.066

Cheng CH, Lehmann J, Thies JE, Burton SD, Engelhard MH (2006) Oxidation of black carbon by biotic and abiotic processes. Org Geochem 37:1477-1488. doi:10.1016/j.orggeochem.2006.06.022

Cheng CH, Lehmann J, Engelhard MH (2008) Natural oxidation of black carbon in soils: changes in molecular form and surface change along a climosequence. Geochim Cosmochim Acta 72:1598-1610. doi: 10.1016/j.gca.2008.01.010

Cheng Y, Cai Z, Chang SX, Wang J, Zhang J (2012) Wheat straw and its biochar have contrasting effects on inorganic $\mathrm{N}$ retention and $\mathrm{N}_{2} \mathrm{O}$ production in a cultivated Black Chernozem. Biol Fertil Soils 48: 941-946. doi:10.1007/s00374-012-0687-0

Clough TJ, Bertram JE, Ray JL, Condron LM, O'Callaghan M, Sherlock RR, Wells NS (2010) Unweathered wood biochar impact on nitrous oxide emissions from a bovine-urine-amended pasture soil. Soil Sci Soc Am J 74:852-860. doi:10.2136/sssaj2009.0185

Compant S, Clément S, Sessitsch A (2010) Plant growth-promoting bacteria in the rhizo- and endosphere of plants: their role, colonization, mechanisms involved and prospects for utilization. Soil Biol Biochem 42:669-678. doi:10.1016/j.soilbio.2009.11.024

Conte P, Marsala V, De Pasquale C, Bubici S, Valagussa M, Pozzi A, Alonzo G (2013) Nature of water-biochar interface interactions. GCB Bioenergy 5:116-121. doi:10.1111/gcbb.12009

Dai Z, Meng J, Muhammad N, Liu X, Wang H, He Y, Brookes PC, Xu J (2013) The potential feasibility for soil improvement, based on the properties of biochars pyrolyzed from different feedstocks. J Soils Sediments 13:989-1000. doi:10.1007/s11368-013-0698-y

De Meyer A, Poesen J, Isabirye M, Deckers J, Rates D (2011) Soil erosion rate in tropical villages: a case study from Lake Victoria Basin, Uganda. Catena 84:89-98. doi:10.1016/j.catena.2010.10.001

Deenik JL, McClellan T, Uehara G, Antal MJ, Campbell S (2010) Charcoal volatile matter content influences plant growth and soil nitrogen transformations. Soil Sci Soc Am J 74:1259-1270. doi: 10.2136/sssaj2009.0115

DeLuca TH, MacKenzie MD, Gundale MJ, Holben WE (2006) Wildfireproduced charcoal directly influences nitrogen cycling in ponderosa pine forests. Soil Sci Soc Am J 70:448-453. doi:10.2136/sssaj2005. 0096

DeLuca TH, MacKenzie MD, Gundale MJ (2009) Biochar effects on soil nutrient transformations. In: Lehmann J, Joseph S (eds) Biochar for environmental management: science and technology. Earthscan, London, pp 251-270

Domene X, Mattana S, Hanley K, Enders A, Lehmann J (2014) Mediumterm effects of corn biochar addition on soil biota activities and 
functions in a temperate soil cropped to corn. Soil Biol Biochem 72: 152-162. doi:10.1016/j.soilbio.2014.01.035

Domene X, Hanley K, Enders A, Lehmann J (2015) Short-term mesofauna responses to soil additions of corn stover biochar and the role of microbial biomass. Appl Soil Ecol 89:10-17. doi:10. 1016/j.apsoil.2014.12.005

Ennis CJ, Evans AG, Islam M, Ralebitso-Senior K, Senior E (2012) Biochar: carbon sequestration, land remediation, and impacts on soil microbiology. Crit Rev Environ Sci Technol 42:2311-2364. doi:10. 1080/10643389.2011.574115

Ezawa T, Yamamoto K, Yoshida S (2002) Enhancement of the effectiveness of indigenous arbuscular mycorrhizal fungi by inorganic soil amendments. Soil Sci Plant Nutr 48:897-900. doi:10.1080/ 00380768.2002.10408718

Gell K, Van Groenigen J, Cayuela ML (2011) Residues of bioenergy production chains as soil 17 amendments: immediate and temporal phytotoxicity. J Hazard Mater 186:2017-2025. doi:10.1016/j. jhazmat.2010.12.105

Genesio L, Miglietta F, Baronti S, Vaccari FP (2015) Biochar increases vineyard productivity without affecting grape quality: results from a four years field experiment in Tuscany. Agric Ecosyst Environ 201: 20-25. doi:10.1016/j.agee.2014.11.021

George N, Davies JT (1988) Parameters affecting adsorption of microorganisms on activated charcoal cloth. J Chem Technol Biotechnol 43: 173-186. doi:10.1002/jctb.280430303

Glaser B, Lehmann J, Zech W (2002) Ameliorating physical and chemical properties of highly weathered soils in the tropics with charcoal-a review. Biol Fertil Soils 35:1719-1730. doi:10.1007/ s00374-002-0466-4

Grossman JM, O’Neill BE, Tsai SM, Liang B, Neves E, Lehmann J, Thies JE (2010) Amazonian anthrosols support similar microbial communities that differ distinctly from those extant in adjacent, unmodified soils of the same mineralogy. Microb Ecol 60:192205. doi:10.1007/s00248-010-9689-3

Hale SE, Alling V, Martinsen V, Mulder J, Breedveld GD, Cornelissen G (2013) The sorption and desorption of phosphate-P, ammonium-N and nitrate-N in cacao shell and corn cob biochars. Chemosphere 91: 1612-1619. doi:10.1016/j.chemosphere.2012.12.057

Hamer U, Marschner B, Brodowski S, Amelung W (2004) Interactive priming of black carbon and glucose mineralization. Org Geochem 35:823-830. doi:10.1016/j.orggeochem.2004.03.003

Jeffery S, Verheijen FGA, Van Der Velde M, Bastos AC (2011) A quantitative review of the effects of biochar application to soils on crop productivity using meta-analysis. Agric Ecosyst Environ 144:175187. doi:10.1016/j.agee.2011.08.015

Jiang C, Yu G, Li Y, Cao G, Yang ZP, Sheng W, Yu W (2012) Nutrient resorption of coexistence species in alpine meadow of the QinghaiTibetan Plateau explains plant adaptation to nutrient-poor environment. Ecol Eng 44:1-9. doi:10.1016/j.ecoleng.2012.04.006

Jianping Z (1999) Soil erosion in Guizhou province of China: a case study in Bijie prefecture. Soil Use Manag 15:68-70. doi:10.1111/j. 1475-2743.1999.tb00067.x

Jien SH, Wang CS (2013) Effects of biochar on soil properties and erosion potential in a highly weathered soil. Catena 110:225-233. doi: 10.1016/j.catena.2013.06.021

Jin H (2010) Characterization of microbial life colonizing biochar and biocharamended soils. PhD Dissertation, Cornell University, Ithaca, NY

Jones DL, Rousk J, Edwards-Jones G, DeLuca TH, Murphy DV (2012) Biochar-mediated changes in soil quality and plant growth in a three year field trial. Soil Biol Biochem 45:113-124. doi:10.1016/j. soilbio.2011.10.012

Joseph SD, Camps-Arbestain M, Lin Y, Munroe P, Chia CH, Hook J, Van Zwieten L, Kimber S, Cowie A, Singh BP (2010) An investigation into the reactions of biochar in soil. Aust J Soil Res 48:501-515. doi: 10.1071/SR10009
Kammann CI, Schmidt HP, Messerschmidt N, Linsel S, Steffens D, Müller C, Koyro HW, Conte P, Joseph S (2015) Plant growth improvement mediated by nitrate capture in co-composted biochar. Sci Report 5:11080. doi:10.1038/srep11080

Kasozi GN, Zimmerman AR, Nkedi-Kizza P, Gao B (2010) Catechol and humic acid sorption onto a range of laboratory-produced black carbons (biochars). Environ Sci Technol 44:6189-6195. doi:10.1021/ es1014423

Kim JS, Sparovek S, Longo RM, De Melo WJ, Crowley D (2007) Bacterial diversity of terra preta and pristine forest soil from the Western Amazon. Soil Biol Biochem 39:648-690. doi:10.1016/j. soilbio.2006.08.010

Koutcheiko S, Monreal CM, Kodama H, McCracken T, Kotlyar L (2007) Preparation and characterization of activated carbon derived from the thermo-chemical conversion of chicken manure. Bioresour Technol 98:2459-2464. doi:10.1016/j.biortech.2006.09.038

Kuzyakov Y, Subbotina I, Chen H, Bogomolova I, Xu X (2009) Black carbon decomposition and incorporation into microbial biomass estimated by ${ }^{14} \mathrm{C}$ labeling. Soil Biol Biochem 41:210-219. doi:10. 1016/j.soilbio.2008.10.016

Laird DA, Fleming P, Davis DD, Horton R, Wang B, Karlen DL (2010) Impact of biochar amendments on the quality of a typical Midwestern agricultural soil. Geoderma 158:443-449. doi:10. 1016/j.geoderma.2010.05.013

Lang T, Jensen AD, Jensen PA (2005) Retention of organic elements during solid fuel pyrolysis with emphasis on the peculiar behavior of nitrogen. Energy Fuel 19:1631-1643. doi:10.1021/ef049739a

Lee Y, Park J, Ryu C, Gang KS, Yang W, Park YK, Jung J, Hyun S (2013) Comparison of biochar properties from biomass residues produced by slow pyrolysis at $500^{\circ} \mathrm{C}$. Bioresour Technol 148:196-201. doi: 10.1016/j.biortech.2013.08.135

Lehmann J, Joseph S (2009) Biochar for environmental management science and technology. Earthscan, London

Lehmann J, Sohi S (2008) Comment on "Fire-derived charcoal causes loss of forest humus". Science 321:1295. doi:10.1126/science. 1160005

Lehmann J, Gaunt J, Rondon M (2006) Bio-char sequestration in terrestrial ecosystems - a review. Mitig Adapt Strateg Glob Chang 11: 403-427. doi:10.1007/s11027-005-9006-5

Lehmann J, Czimczik C, Laird C, Sohi S (2009) Stability of biochar in soil. In: Lehmann J, Josep S (eds) Biochar for environmental management: science and technology. Earthscan, London

Lehmann J, Rillig MC, Thies J, Masiello CA, Hockaday WC, Crowley D (2011) Biochar effects on soil biota - a review. Soil Biol Biochem 43:1812-1836. doi:10.1016/j.soilbio.2011.04.022

Liang B, Lehmann J, Solomon D, Kinyangi J, Grossman J, O’Neill B, Skjemstad JO, Thies J, Luizão FJ, Petersen J, Neves EG (2006) Black carbon increases cation exchange capacity in soil. Soil Sci Soc Am J 70:1719-1730. doi:10.2136/sssaj2005.0383

Liang B, Lehmann J, Sohi SP, Thies JE, O’Neill B, Trujillo L, Gaunt J, Solomon D, Grossman J, Neves EG, Luizão FJ (2010) Black carbon affects the cycling of non-black carbon in soil. Org Geochem 41: 206-213. doi:10.1016/j.orggeochem.2009.09.007

Liesch AM, Weyers SL, Gaskin JW, Das KC (2010) Impact of two different biochars on earthworm growth and survival. Ann Environ Sci $4: 1-9$

Lin Y, Munroe P, Joseph S, Henderson R, Ziolkowski A (2012) Water extractable organic carbon in untreated and chemical treated biochars. Chemosphere 87:151-157. doi:10.1016/j.chemosphere. 2011.12.007

Liu X, Qu J, Li L, Zhang A, Jufeng Z, Zheng J, Pan G (2012) Can biochar amendment be an ecological engineering technology to depress $\mathrm{N}_{2} \mathrm{O}$ emission in rice paddies? A cross site field experiment from South China. Ecol Eng 42:168-173. doi:10.1016/j.ecoleng.2012.01.016

Liu Z, Chen X, Jing Y, Li Q, Zhang J, Huang Q (2014) Effects of biochar amendment on rapeseed and sweet potato yields and water stable 
aggregate in upland red soil. Catena 123:45-51. doi:10.1016/j. catena.2014.07.005

Lu SG, Sun FF, Zong YT (2014) Effect of rice husk biochar and coal fly ash on some physical properties of expansive clayey soil (Vertisol). Catena 114:37-44. doi:10.1016/j.catena.2013.10.014

Major J, Rondon M, Molina D, Riha SJ, Lehmann J (2010) Maize yield and nutrition during 4 years after biochar application to a Colombian savanna oxisol. Plant Soil 333:117-128. doi:10.1007/s11104-010-0327-0

Masto RE, Ansari MA, George J, Selvi V, Ram L (2013) Co-application of biochar and lignite fly ash on soil nutrients and biological parameters at different crop growth stages of Zea mays. Ecol Eng 58:314 322. doi:10.1016/j.ecoleng.2013.07.011

Mengel K, Kirkby EA (2001) Principles of plant nutrition, 5th edn. Kluwer Academic Publishers, Dordrecht

Mizuta K, Matsumoto T, Hatate Y, Nishihara K, Nakanishi T (2004) Removal of nitrate-nitrogen from drinking water using bamboo powder charcoal. Bioresour Technol 95:255-257. doi:10.1016/j. biortech.2004.02.015

Morales M, Comerford N, Guerrini I, Falcão N, Reeves J (2013) Sorption and desorption of phosphate on biochar and biochar-soil mixtures. Soil Use Manag 29:306-314. doi:10.1111/sum.12047

Mukherjee A, Zimmerman AR (2013) Organic carbon and nutrient release from a range of laboratory-produced biochars and biochar-soil mixtures. Geoderma 193:122-130. doi:10.1016/j.geoderma.2012.10.002

Nelissen V, Saha BK, Ruysschaert G, Boeckx P (2014) Effect of different biochar and fertilizer types on $\mathrm{N}_{2} \mathrm{O}$ and $\mathrm{NO}$ emissions. Soil Biol Biochem 70:244-255. doi:10.1016/j.soilbio.2013.12.026

Nelissen V, Ruysschaert G, Manka'Abusi D, D’Hose T, De Beuf K, Al-Barri B, Cornelis W, Boeckx P (2015) Impact of a woody biochar on properties of a sandy loam soil and spring barley during a two-year field experiment. Eur J Agron 62:65-78. doi:10.1016/j.eja.2014.09.006

Noguera D, Rondón M, Laossi KR, Hoyos V, Lavelle P, de Carvalho MHC, Barot S (2010) Contrasted effect of biochar and earthworms on rice growth and resource allocation in different soils. Soil Biol Biochem 42:1017-1027. doi:10.1016/j.soilbio.2010.03.001

Novak JM, Busscher WJ (2013) Selection and use of designer biochars to improve characteristics of southeastern USA Coastal Plain degraded soils. Advanced biofuels and bioproducts. Springer, New York, pp 69-96

O’Neill B, Grossman J, Tsai MT, Gomes JE, Lehmann J, Peterson J, Neves E, Thies JE (2009) Bacterial community composition in Brazilian Anthrosols and adjacent soils characterized using culturing and molecular identification. Microb Ecol 58:23-35. doi:10.1007/ s00248-009-9515-y

Oguntunde P, Fosu M, Ajayi A, Giesen N (2004) Effects of charcoal production on maize yield, chemical properties and texture of soil. Biol Fertil Soils 39:295-299. doi:10.1007/s00374-003-0707-1

Page AL, Miller RH, Keeney DR (1982) Methods of soil analysis: chemical and microbiological properties, 2nd edn. American Society of Agronomy Inc, Madison

Park JH, Choppala GK, Bolan NS, Chung JW, Chuasavathi T (2011) Biochar reduces the bioavailability and phytotoxicity of heavy metals. Plant Soil 348:439-451. doi:10.1007/s11104-011-0948-y

Paz-Ferreiro J, Gascó G, Gutiérrez B, Méndez A (2012) Soil biochemical activities and the geometric mean of enzyme activities after application of sewage sludge and sewage sludge biochar to soil. Biol Fertil Soils 48:511-517. doi:10.1007/s00374-011-0644-3

Peake LR, Reid BJ, Tang X (2014) Quantifying the influence of biochar on the physical and hydrological properties of dissimilar soils. Geoderma 235:182-190. doi:10.1016/j.geoderma.2014.07.002

Pietikäinen J, Kiikkilä O, Fritze H (2000) Charcoal as a habitat for microbes and its effect on the microbial community of the underlying humus. Oikos 89:231-242. doi:10.1034/j.1600-0706.2000.890203.x

Pollock MR (1947) The growth of H. pertussis on media without blood. Br J Exp Pathol 28:295-307

Prayogo C, Jones JE, Baeyens J, Bending GD (2014) Impact of biochar on mineralisation of $\mathrm{C}$ and $\mathrm{N}$ from soil and willow litter and its relationship with microbial community biomass and structure. Biol Fertil Soils 50:695-702. doi:10.1007/s00374-013-0884-5

Rajkovich S, Enders A, Hanley K, Hyland C, Zimmerman AR, Lehmann J (2012) Corn growth and nitrogen nutrition after additions of biochars with varying properties to a temperate soil. Biol Fertil Soils 48: 271-284. doi:10.1007/s00374-011-0624-7

Rillig MC, Mummey DL (2006) Mycorrhizas and soil structure. New Phytol 171:41-53. doi:10.1111/j.1469-8137.2006.01750.x

Rillig MC, Wagner M, Salem M, Antunes PM, George C, Ramke HG, Titirici MM, Antonietti M (2010) Material derived from hydrothermal carbonization: effects on plant growth and arbuscular mycorrhiza. Appl Soil Ecol 45:238-242. doi:10.1016/j.apsoil.2010.04.011

Rogovska N, Laird DA, Rathke SJ, Karlen DL (2014) Biochar impact on Midwestern Mollisols and maize nutrient availability. Geoderma 230:340-347. doi:10.1016/j.geoderma.2014.04.009

Rondon M, Ramirez J, Lehmann J (2005) Charcoal additions reduce net emissions of greenhouse gases to the atmosphere. In: Proceedings of the 3rd USDA Symposium on Greenhouse Gases and Carbon Sequestration in Agriculture and Forestry. Baltimore, MD, p 208

Rousk J, Bååth E, Brookes PC, Lauber CL, Lozupone C, Caporaso JG, Knight R, Fierer N (2010) Soil bacterial and fungal communities across a $\mathrm{pH}$ gradient in an arable soil. ISME J 4:134-151. doi:10. 1038/ismej.2010.58

Saito M, Marumoto T (2002) Inoculation with arbuscular mycorrhizal fungi: the status quo in Japan and the future prospects. Plant Soil 244:273-279. doi:10.1007/978-94-017-1284-2_27

Scheer C, Grace PR, Rowlings DW, Kimber S, Van Zwieten L (2011) Effect of biochar amendment on the soil-atmosphere exchange of greenhouse gases from an intensive subtropical pasture in northern New South Wales, Australia. Plant Soil 345:47-58. doi:10.1007/ s11104-011-0759-1

Schimel J, Balser TC, Wallenstein M (2007) Microbial stress-response physiology and its implications for ecosystem function. Ecology 88: 1386-1394. doi:10.1890/06-0219

Schmidt HP, Pandit BH, Martinsen V, Cornelissen G, Conte P, Kammann CI (2015) Fourfold increase in pumpkin yield in response to low-dosage root zone application of urine-enhanced biochar to a fertile tropical soil. Agriculture 5:723-741. doi:10.3390/agriculture5030723

Schwartz MW, Hoeksema JD, Gehring CA, Johnson NC, Klironomos JN, Abbott LK, Pringle A (2006) The promise and the potential consequences of the global transport of mycorrhizal fungal inoculum. Ecol Lett 9:501-515. doi:10.1111/j.1461-0248.2006.00910.x

Silber A, Levkovitch I, Graber ER (2010) PH-dependent mineral release and surface properties of cornstrawdbiochar: agronomic implications. Environ Sci Technol 44:9318-9323. doi:10.1021/es101283d

Singh BP, Hatton BJ, Balwant S, Cowie AL, Kathuria A (2010) Influence of biochars on nitrous oxide emission and nitrogen leaching from two contrasting soils. J Environ Qual 39:1224-1235. doi:10.2134/ jeq2009.0138

Sohi SP, Krull E, Lopez-Capel E, Bol R (2010) A review of biochar and its use and function in soil. Adv Agron 105:47-82. doi:10.1016/ S0065-2113(10)05002-9

Sollins P, Robertson GP, Uehara G (1988) Nutrient mobility in variableand permanent charge soils. Biogeochemistry 6:181-199. doi:10. 1007/BF02182995

Spokas KA, Koskinen WC, Baker JM, Reicosky DC (2009) Impacts of woodchip biochar additions on greenhouse gas production and sorption/degradation of two herbicides in a Minnesota soil. Chemosphere 77:574-581. doi:10.1016/j.chemosphere.2009.06.053

Spokas KA, Baker JM, Reicosky DC (2010) Ethylene: potential key for biochar amendment impacts. Plant Soil 333:443-452. doi:10.1007/ s11104-010-0359-5

Spokas KA, Novak JM, Stewart CE, Cantrell KB, Uchimiya M, DuSaire MG, Ro KS (2011) Qualitative analysis of volatile organic compounds on biochar. Chemosphere 85:869-882. doi:10.1016/j. chemosphere.2011.06.108 
Spokas KA, Novak JM, Venterea RT (2012) Biochar's role as an alternative N fertilizer: ammonia capture. Plant Soil 350:35-42. doi:10. 1007/s11104-011-0930-8

Steiner C, Das KC, Garcia M, Förster B, Zech W (2008a) Charcoal and smoke extract stimulate the soil microbial community in a highly weathered xanthic Ferralsol. Pedobiologia 51:359-366. doi:10. 1016/j.pedobi.2007.08.002

Steiner C, Glaser B, Teixeira WG, Lehmann J, Blum WEH, Zech W (2008b) Nitrogen retention and plant uptake on a highly weathered central Amazonian Ferralsol amended with compost and charcoal. J Plant Nutr Soil Sci 171:893-899. doi:10.1002/jpln.200625199

Stewart CE, Zheng J, Botte J, Cotrufo MF (2012) Co-generated fast pyrolysis biochar mitigates greenhouse gas emissions and increases carbon sequestration in temperate soils. GCB Bioenergy 5:153-164. doi:10.1111/gcbb.12001

Swiatkowski A, Pakula M, Biniak S, Walczyk M (2004) Influence of the surface chemistry of modified activated carbon on its electrochemical behaviour in the presence of lead (II) ions. Carbon 42:30573069. doi:10.1016/j.carbon.2004.06.043

Taghizadeh-Toosi A, Clough TJ, Condron LM, Sherlock RR, Anderson CR, Craigie RA (2011) Biochar incorporation into pasture soil suppresses in situ nitrous oxide emissions from ruminant urine patches. J Environ Qual 40:468-476. doi:10.2134/jeq2010.0419

Taghizadeh-Toosi A, Clough TJ, Sherlock RR, Condron LM (2012) Biochar adsorbed ammonia is bioavailable. Plant Soil 350:57-69. doi:10.1007/s11104-011-0870-3

Taketani RG, Tsai SM (2010) The influence of different land uses on the structure of archaeal communities in Amazonian Anthrosols based on 16S rRNA and amoA genes. Microb Ecol 59:734-743. doi:10. 1007/s00248-010-9638-1

Taylor CB (1951) The nutritional requirements of the predominant bacterial flora of soil. J Appl Microbiol 14:101-111. doi:10.1111/j. 1365-2672.1951.tb01999.x

Thies JE, Rillig M (2009) Characteristics of biochar: biological properties. In: Lehmann J, Joseph S (eds) Biochar for environmental management: science and technology. Earthscan, London, pp 85-105

Tsai WT, Liu SC, Chen HR, Chang YM, Tsai YL (2012) Textural and chemical properties of swine-manure-derived biochar pertinent to its potential use as a soil amendment. Chemosphere 89:198-203. doi: 10.1016/j.chemosphere.2012.05.085

Turner ER (1955) The effect of certain adsorbents on the nodulation of clover plants. Ann Bot 19:149-160

Uzoma KC, Inoue M, Andry H, Fujimaki H, Zahoor A, Nishihara E (2011) Effect of cow manure biochar on maize productivity under sandy soil condition. Soil Use Manag 27:205-212. doi:10.1111/j. 1475-2743.2011.00340.x

Van de Voorde TF, Van Noppen F, Nacheniu RW, Prins W, Mommer L, Van Groenigen JW, Bezemer TM (2014) Biochars produced from individual grassland species differ in their effect on plant growth. Basic Appl Ecol 15:18-25. doi:10.1016/j.baae.2013.12.005

Van Zwieten L, Singh BP, Joseph S, Kimber S, Cowie A, Chan KY (2009) Biochar and emissions of non- $\mathrm{CO}_{2}$ greenhouse gases from soil. In: Lehmann J, Joseph S (eds) Biochar for environmental management: science and technology. Earthscan, London, pp 227-249

Wang Z, Zheng H, Luo Y, Deng X, Herbert S, Xing B (2013) Characterization and influence of biochars on nitrous oxide emission from agricultural soil. Environ Pollut 174:289-296. doi:10.1016/j. envpol.2012.12.003

Wang Y, Yin R, Liu R (2014) Characterization of biochar from fast pyrolysis and its effect on chemical properties of the tea garden soil. $\mathrm{J}$ Anal Appl Pyrol 110:375-381. doi:10.1016/j.jaap.2014.10.006

Wardle DA, Yeates GW, Nicholson KS, Bonner KI, Watson RN (1999) Response of soil microbial biomass dynamics, activity and plant litter decomposition to agricultural intensification over a sevenyear period. Soil Biol Biochem 31:1707-1720. doi:10.1016/ S0038-0717(99)00090-5

Wardle DA, Nilsson MC, Zackrisson O (2008) Fire-derived charcoal causes loss of forest humus. Science 320:629-629. doi:10.1126/ science. 1154960

Warnock DD, Lehmann J, Kuyper TW, Rillig MC (2007) Mycorrhizal responses to biochar in soil - concepts and mechanisms. Plant Soil 300:9-20. doi:10.1007/s11104-007-9391-5

Woolf D, Lehmann J (2012) Modelling the long-term response to positive and negative priming of soil organic carbon by black carbon. Biogeochemistry 111:83-95. doi:10.1007/s10533-012-9764-6

Wu HW, Yip K, Kong ZY, Li CZ, Liu DW, Yu Y, Gao XP (2011) Removal and recycling of inherent inorganic nutrient species in mallee biomass and derived biochars by water leaching. Ind Eng Chem Res 50:12143-12151. doi:10.1021/ie200679n

Xu G, Sun J, Shao H, Chang SX (2014) Biochar had effects on phosphorus sorption and desorption in three soils with differing acidity. Ecol Eng 62:54-60. doi:10.1016/j.ecoleng.2013.10.027

Yanai Y, Toyota K, Okazaki M (2007) Effects of charcoal addition on $\mathrm{N}_{2} \mathrm{O}$ emissions from soil resulting from rewetting air-dried soil in short-term laboratory experiments. Soil Sci Plant Nutr 53:181-188. doi:10.1111/j.1747-0765.2007.00123.x

Yang L, Liao F, Huang M, Yang L, Li Y (2015) Biochar improves sugarcane seedling root and soil properties under a pot experiment. Sugar Tech 17:36-40. doi:10.1007/s12355-014-0335-0

Yao Y, Gao B, Zhang M, Inyang M, Zimmerman AR (2012) Effect of biochar amendment on sorption and leaching of nitrate, ammonium, and phosphate in a sandy soil. Chemosphere 89:1467-1471. doi:10. 1016/j.chemosphere.2012.06.002

Ye L, Zhang J, Zhao J, Luo Z, Tu S, Yin Y (2015) Properties of biochar obtained from pyrolysis of bamboo shoot shell. J Anal Appl Pyrol 114:172-178. doi:10.1016/j.jaap.2015.05.016

Yuan J, Xu R, Zhang H (2011) The forms of alkalis in the biochar produced from crop residues at different temperatures. Bioresour Technol 102:3488-3497. doi:10.1016/j.biortech.2010.11.018

Zhang A, Cui L, Pan G, Li L, Hussain Q, Zhang X, Zheng J, Crowley D (2010) Effect of biochar amendment on yield and methane and nitrous oxide emissions from a rice paddy from Tai Lake Plain, China. Agric Ecosyst Environ 139:469-475. doi:10.1016/j.agee.2010.09.003

Zhang P, Sun H, Yu L, Sun T (2013) Adsorption and catalytic hydrolysis of carbaryl and atrazine on pig manure-derived biochars: impact of structural properties of biochars. J Hazard Mater 244:217-224. doi: 10.1016/j.jhazmat.2012.11.046

Zhang H, Voroney R, Price G (2015) Effects of temperature and processing conditions on biochar chemical properties and their influence on soil C and N transformations. Soil Biol Biochem 83:19-28. doi:10. 1016/j.soilbio.2015.01.006

Zheng H, Wang Z, Deng X, Zhao J, Luo Y, Novak J, Herbert S, Xing B (2013) Characteristics and nutrient values of biochars produced from giant reed at different temperatures. Bioresour Technol 130: 463-471. doi:10.1016/j.biortech.2012.12.044

Zhu D, Pignatello JJ (2005) Characterization of aromatic compound sorptive interactions with black carbon (charcoal) assisted by graphite as a model. Environ Sci Technol 39:2033-2041. doi:10.1021/es0491376

Zimmerman AR (2010) Abiotic and microbial oxidation of laboratoryproduced black carbon (biochar). Environ Sci Technol 44:12951301. doi:10.1021/es903140c

Zimmerman A, Gao B, Ahn MY (2011) Positive and negative carbon mineralization priming effects among a variety of biochar amended soils. Soil Biol Biochem 43:1169-1179. doi:10.1016/j.soilbio.2011. 02.005 